\title{
EREBEA
}

Revista de Humanidades

y Ciencias Sociales

NúM. 4 (2014), pp. 81-118

ISSN: 0214-0691

\section{Las madres del bien morir del Hospital de las Cinco Llagas de Sevilla en el Antiguo Régimen}

\author{
Paula Ermila Rivasplata Varillas \\ Universidad de Sevilla
}

RESUMEN

Después del Concilio de Trento, el morir y el purgatorio cobraron gran importancia en la vida de los católicos. En instituciones regidas por la Iglesia como el hospital de las Cinco Llagas de Sevilla surgieron otras personas que ayudaban a los curas a bien morir. Se trataba de la "madre agonizante" que se encargaba de ayudar a las moribundas a morir en paz que ejecutaba desde que el médico o cirujano ordenaba administrar el Santo Óleo de la extremaunción. Estas madres debían saber leer para estimular y exhortar a las que se hallasen en este estado con algunas invocaciones $\mathrm{u}$ oraciones. Tampoco, estas mujeres se podían apartar de la cabecera de la enferma de día ni de noche, siguiendo las órdenes de su jefa inmediata, la madre mayor. Una vez que la moribunda fallecía, se encargaba de ayudar a amortajarla y guardar en un cofre las pertenencias de las agonizantes.

Palabras Clave

Sevilla, Hospital de las Cinco Llagas, madre del bien morir, Antiguo Régimen, muerte.

Fecha de recepción: 22 de abril de 2014 Fecha de aceptación: 23 de octubre de 2014
Abstract

After the Council of Trent, the death and purgatory became very important in the life of Catholics. In institutions governed by the Church like the hospital of the Five Wounds of Seville need people to help to the priest to die well to the moribunds. The mother of the good death was responsible for helping the sick to die peacefully, which ran from the ordering physician or surgeon to give the extreme unction. They were also required to not move from the bedside of the sick day or night, following the orders of her superioriy, "la madre mayor". "These mothers of the good death" must know to read to encourage and exhort the moribunds with some invocations or prayers. Once the sick person died, "the mother of the good death" was responsible for helping to lay out the dead and keep belongings in a chest of the dying

KEYWORDS

Seville, Hospital of the Five Wounds, The mother of the good death, Ancient regime, death. 

Este trabajo es una primera aproximación a la figura de la madre del bien morir y de su participación en el proceso de preparación para la muerte en un hospital andaluz en el Antiguo Régimen, en este caso del hospital de las Cinco Llagas de Sevilla. Este trabajo se ha realizado a partir de las constituciones, libros y legajos del hospital de las Cinco Llagas, resguardados en el Archivo de la Diputación Provincial de Sevilla. Este hospital tuvo cuatro constituciones o reglamentos, 1503, 1603, 1624 y $1734 .{ }^{1}$ Estas fuentes primarias fueron normas básicas de gobierno que me permitieron conocer la organización y el funcionamiento interno del hospital, los deberes y obligaciones de los trabajadores del hospital, las visitas de control a las enfermerías por los médicos, cirujanos, administrador y priores, los castigos a las infracciones, las denuncias de abusos, etc. Estos cuatro reglamentos proporcionan una visión general desde la propia institución. Específicamente, detallan los deberes de las mujeres que se ocupaban del bien morir.

Indudablemente las constituciones no fueron suficientes para la elaboración de este trabajo y se recurrió a libros y legajos elaborados por secretarios notarios eclesiásticos de este hospital. Las constituciones se renovaban según los acuerdos tomados en las juntas patronales. Estos libros capitulares han sido la fuente documental más utilizada en esta investigación porque nos revelan los acontecimientos cotidianos del hospital. Estos libros son los más ricos en información y suponen en gran medida la base documental de este trabajo. También se han utilizado el libro protocolo, los libros de cuentas, recibos y gastos, los inventarios, los libros de salarios, los testamentos, los libros de almonedas, los libros de capellanías y misas, los libros de entrada y salida de enfermas y los planos.

Los libros y legajos presentan algunas lagunas y errores de duplicidad, especialmente en el siglo XVI y comienzos del XVII que fueron épocas en las cuales la ciudad y el hospital atravesaron agudas crisis económicas (1683-1687) (17111729) y sociales, como consecuencia de las epidemias de peste de 1649 y 1709. Pasadas estas crisis, hay un periodo de silencio en la documentación hospitalaria que al cabo de algunos años se supera.

1 Las constituciones del hospital de las Cinco Llagas de Sevilla de 1503, 1603 y 1624 se encuentran en el Archivo de la Diputación Provincial de Sevilla (ADPS).Las constituciones de 1503 y 1624 se localizan en la Sección Fundación y Gobierno, legajo 1 y la de 1603 en la sección administración de propiedades, legajo 6. La constitución de 1734 se encuentra en la Biblioteca Colombina (BC). Fondo Gestoso. Tomo V, Fol. 175 a 244. 
El objetivo de esta investigación ha sido poner a la luz el trabajo desempeñado por las mujeres encargadas del bien morir y el ritual de la muerte en el hospital de las Cinco Llagas de Sevilla durante todo el Antiguo Régimen. No ha sido posible encontrar bibliografía al respecto, sólo escuetas menciones de mujeres que se dedicaban a esto en alguna bibliografía, pero sin desarrollarla. ${ }^{2}$ El buen morir no sólo lo ejecutaban los curas, sino también cualquier persona que estuviese dispuesta a ello, por la gran necesidad que había de acompañantes. Incluso un libro destinado a estas personas se publicó en 1630 que lleva el título Práctica de ayuda a morir. Para que cualquiera que supiere leer, pueda en ausencia de los sabios confesores, guiar y consolar a los enfermos. Su autor fue el jesuita Juan Bautista de Poza.

En el Ars bene moriendi se concedía gran importancia a la presencia del asistente que acompañaba al moribundo, después que el sacerdote cumplía con el ritual que le correspondía. El asistente podía ser hombre o mujer, que conociese la doctrina cristiana y que estuviese consciente de que la agonía era la última oportunidad de salvación. ${ }^{3}$ Este trabajo no lo cumplía necesariamente un clérigo en lugares donde tuviese mucha carga laboral, como los hospitales. Ante esta situación, Juan Bautista de Poza indicaba en su libro mencionado que cualquiera que supiese leer, podía asistir a un moribundo:

Los hombres sabios que pueden ayudar a morir y consolar y alentar y encaminar a los enfermos son pocos. El peligro de la enfermedad suele durar por mucho tiempo y la asistencia del prudente confesor raras veces puede ser continua. Otros religiosos y sacerdotes, es fuerza, hagan muchas ausencias para acudir a sus obligaciones. Por todas estas causas parece necesario enseñar a que ayuden a bien morir los que para este ministerio tuviesen capacidad y la tendrán valiéndose de esta obra todos los que supiesen leer. ${ }^{4}$

2 M. M. Rivera Garretas. "Las beguinas y beatas, las trovadoras y las cataras: el sentido libre de ser mujer", en Morant, I. (dir.), Historia de las mujeres en España y América Latina de la prehistoria a la edad Media, Madrid, Ediciones Cátedra, Tomo I, 2005, pp. 745-767; M.M. Rivera Garretas. "La libertad femenina en las instituciones religiosas medievales", en Anuario de Estudios Medievales, 28, 1998, pp. 553-565. M. Ortega López. "El periodo Barroco (1565-1770)", en Historia de las mujeres de España. Madrid: Editorial Síntesis, 1997, pp. 297 y 299. Las mujeres eran las que curaban a los enfermos y amortajaban a los muertos en la vida cotidiana. En Sevilla, a finales del siglo XVI, varias beatas trabajaban en el hospital de la ciudad y recibían su salario a través del ayuntamiento e incluso trabajaban en las cárceles.

3 A.L. Haindl Ugarte. "Ars bene moriendi: el arte de la buena muerte", en Revista chilena de estudios medievales. Numero 3, enero-junio, 2013, p. 93.

4 J. Bautista de Poza (1588-1659).Practica de ayuda a morir. Para que cualquiera que supiere leer, pueda en ausencia de los sabios confesores, guiar y consolar a los enfermos. Impreso en Sevilla, por Francisco de Lyra, 1630, folios 1r-2v. 
La demanda en asistir a los agonizantes hizo que surgieran cofradías y hermandades que se dedicaban al bien morir porque la muerte era un acto público en donde se demostraba la solidaridad con el agonizante en su postrera lucha final. ${ }^{5}$ De esta manera, este artículo pretende hacer un seguimiento del trabajo desempeñado por las madres agonizantes del hospital de las Cinco Llagas, el por qué surgieron, en el marco de qué contexto, la importancia que adquirieron a medida que pasaron los siglos y su paulatina desaparición.

\section{El hospital de las Cinco Llagas de Sevilla}

Este hospital fue fundado en 1500 por Catalina de Ribera y Mendoza, esposa de don Pedro Enríquez de Ribera, adelantado mayor de Andalucía. Se destinó a mujeres pobres con enfermedades que no fuesen incurables ni contagiosas, recibiéndose enfermas de calenturas, de cámaras (diarreas), heridas, postemas (abscesos supurados), llagas frescas (úlceras), fracturas y dislocaciones. ${ }^{6}$ Dotó al hospital con un cuantioso patrimonio y obtuvo el permiso, licencia y autoridad del papa Alejandro VI en dos bulas, las de 1500 y 1502. El 20 de marzo de 1503 se presentó la bula del Papa Alejandro VI frente a notario público y testigos en el monasterio de San Isidoro del Campo, extramuros de la ciudad de Sevilla. También, Clemente VIII y Pío IV dieron bulas que concedían el privilegio de la excepción de la jurisdicción ordinaria. ${ }^{7}$ La expedida por Clemente VII en Roma el 26 de octubre

5 S. Gómez Navarro. Materiales para la experiencia del morir en la Córdoba del Antiguo Régimen. Córdoba: Servicio de publicaciones de la OCO, 1998, p. 75. Se creía que los agonizantes pasaban por un proceso de lucha entre ángeles y demonios para ganar su alma. Etapa fundamental que necesitaba de guía para bien morir que lo asumían los curas u otra persona preparada para eso, con preces, oraciones, jaculatorias, recomendaciones a Jesucristo, Virgen, Santos, ángeles, arcángeles y toda la corte celestial, salmos, letanías, platicas, lecturas de libros sagrados o religiosos, petición de perdón, etc.; M. de Yebra (O.F.M.) Libro llamado refugium infirmoru, muy útil y provechosos para todo género de gente. En Madrid, por Luis Sánchez, 1593, pp. 106.-110. Que aparecen muchas veces los demonios a los hombres y en especial a la hora de la muerte; A. Bazarte Martínez. Las cofradias de españoles en la ciudad de México (1526-1864). México: Universidad Autonomía Metropolitana, 1989, p. 28. Algunas cofradías tenían la misión de ayudar a bien morir; M. J. de Lara Ródenas. Muerte y religiosidad en la Huelva del Barroco. Huelva: Publicaciones de la Universidad de Huelva, 1998, cap.5 Menciona las Reglas y obligaciones que han de observar los que vistieren el Sagrado Escapulario y se asentaren por siervos y esclavos de Maria Santísima Dolorosa en la congregación fundada y establecida en el convento de los RR.PP. Mercenarios Descalzos de la villa de Huelva. Esta cofradía podía elegir un sacerdote y un lego llamados enfermeros para que visitaran a los enfermos y no faltaran a la hora de la muerte.

6 ADPS. Legajo 1 A. Las Constituciones del hospital de las Cinco Llagas de Sevilla de 1624, f.1 v. Artículo 4 y las Constituciones del hospital de las Cinco Llagas de Sevilla de 1734. Artículo 10; D. López Falante y M. de la Paz de la Torre Liébana. "El Hospital de las Cinco Llagas de Sevilla: un modelo de organización de instituciones de beneficencia durante el Antiguo Régimen", en Archivo Hispalense, Sevilla, Tomo LXXVIII. No 237, 1995, pp. 61-77.

7 ADPS. Legajo 4 B. Autos capitulares de este hospital de la Sangre comienza año de 1716 y acaba año de 1734., f. 78 v (1727); J. I. Carmona García, "Cinco siglos de historia: trayectoria 
de 1524 indicaba que el hospital estaba bajo su protección, con la exclusión de cualquier otra autoridad civil o eclesiástica, so pena de excomunión y el pago de mil ducados destinado a la construcción de la iglesia San Pedro en Roma. ${ }^{8}$ Sus principales funciones eran la asistencia en la enfermedad, convalecencia y en la agonía. Aunque es necesario tener en cuenta que del centenar de hospitales existentes en Sevilla en el siglo XVI, una mínima parte cumplía la función de curar enfermedades, pues el término hospital aún abarcaba usos distintos, como hospederías, centros de caridad, orfanatos y centros gremiales. ${ }^{9}$ Este hospital no fue creado para albergue de menesterosos, aunque se utilizó en parte como hospicio a partir de 1750. También cumplió el papel de cobijar a los enfermos durante las grandes pestes que asolaron Sevilla.

El hospital de las Cinco Llagas fue fundado con fondos particulares como tantos otros en España. Sus fundadores Catalina de Ribera y su hijo don Fabrique, I marqués de Tarifa, habían entregado el hospital a la Iglesia para su gobierno, renunciando a todo tipo de beneficio. También, dispusieron que los patronos, administradores y visitadores del hospital serían los padres priores de los monasterios de Santa María de las Cuevas de la orden Cartuja, de San Jerónimo de Buenavista y de San Isidoro de Campo, ambos de la orden de San Jerónimo. ${ }^{10}$ En 1626 se pretendió eliminar como patrono al prior de San Isidoro del Campo, pero sin éxito alguno. ${ }^{11} \mathrm{~A}$ lo largo de más de tres siglos, la administración fue llevada a cabo por un priorato, cuya presidencia se turnaba entre las tres sedes religiosas que la regían.

Este hospital empezó a funcionar en un modesto local a comienzos del siglo XVI con un sacerdote, una matrona, criadas y esclavas. Paulatinamente, se incorporaron el boticario, el botiller y el mayordomo. Mientras tanto se estaba construyendo un edificio renacentista a extramuros de la ciudad, de planta rec-

institucional y asistencial del Hospital de la Sangre”, en El edificio sede del parlamento de Andalucía. El Hospital de las Cinco Llagas. Sevilla: Parlamento de Andalucía, 2007, p. 81. El hospital dependía de la autoridad papal.

8 ADPS. Legajo 4C. Libro de auto capitular del hospital de la Sangre, comienzo del año de 1788 a 1800. (1820). Folios sueltos; F. Collantes de Terán, Los establecimientos de caridad de Sevilla. Sevilla: Colegio oficial de Aparejadores y arquitectos técnicos de Sevilla, 1980, pp. 131-33. Este hospital recibió privilegios.

9 F. Hernández Martín. Historia de la enfermería en España: Desde la antigüedad hasta nuestros dias. Madrid: Síntesis, 1996, p. 128. La gran cantidad de hospitales en Sevilla obligó a su reducción en 1586, de setenta y seis hospitales a dos: el de Santa Catalina de los Desamparados u hospital del Espíritu Santo (para llagas) y el hospital del Amor de Dios (para calenturas).

10 A. Navagero, Viaje por España (1524-1526). Madrid: Ediciones Turner, 1983, p.35. Los monasterios de San Jerónimo, Santa María de las Cuevas y San Isidoro eran los más importantes monasterios a extramuros de Sevilla a comienzos del XVI.

11 E. Domínguez-Rodiño y Domínguez Adame. "El hospital de las Cinco Llagas", en Hospitales de Sevilla. Utrera: Real Academia Sevillana de Buenas Letras, Grafitres S. L.: 1989, pp. 89-117. 
tangular con una cruz griega en la parte central donde se ubicaría la iglesia que estaba rodeada de salas alineadas comunicadas entre si, en dos plantas y cuatro patios cuadrados, siendo un fiel reflejo del Hospital Maggiore de Milano. ${ }^{12} \mathrm{Al}$ trasladarse a su nuevo local en el hermoso edificio renacentista mencionado su personal aumentó y en el siglo XVIII estaba conformado por un administrador, dos curas, dos sacristanes, un médico, un cirujano, un boticario, un ayudante de boticario, un abogado, un procurador, un despensero, un portero, un caballerizo, un jardinero, un herrador, una madre mayor, una madre ayudante, varias enfermeras para las distintas especialidades del hospital, dos madres agonizantes, una portera, una tornillera, una cocinera, varias sirvientas e incluso esclavas.

Este hospital tenía un área de enfermería, cirugía, convalecencia, incurables, agonizantes, cocina y lavadero. La responsable de las mujeres que trabajaban en el hospital era la madre mayor que tenía doce auxiliares que controlaban a las sirvientas de cada área. ${ }^{13}$ Las enfermas del hospital sólo eran atendidas por mujeres, aunque entraban a ciertas horas del día el médico, el cirujano, el boticario, el administrador y el cura semanero. Una vez al mes un prior del hospital entraba a las enfermerías femeninas para realizar la visita obligatoria. ${ }^{14}$

Las madres eran las autoridades superiores de la sala de enfermería femenina. Personas de dedicación exclusiva al hospital, prefiriéndose a viudas y solteras. No tenían que ser necesariamente religiosas, sólo se les exigía que fueran personas de buenas costumbres y cristianas aunque hubo beatas, especialmente en el área de agonizantes.

\section{El bien morir en el Antiguo Régimen}

$\mathrm{El}$ ars moriendi surgió durante el Concilio de Constanza en el siglo XV y fomentaba una actitud pacífica y positiva ante la muerte, pues el buen morir era

12 J. R. Zaragoza Rubira. "La evolución histórica de la asistencia hospitalaria”, en Hospitales de Sevilla. Utrera: Real Academia Sevillana de Buenas Letras. Grafitres S. L., 1989, pp.134-135. Otros hospitales españoles con similar arquitectura son el hospital General de Valencia, el hospital de la Santa Cruz de Toledo y el hospital de los Reyes de Granada; M. Justiniano y Martínez. Hospital de las Cinco Llagas (central) de Sevilla. Sevilla: Imprenta Provincial, 1963, pp. 7-10. Se trasladaría esa idea al Nuevo Mundo; F. Guerra. El hospital en Hispanoamérica y Filipinas 1492-1898. Madrid: Ministerio de Sanidad y Consumo, Servicio de Publicaciones, 1994, pp. 40 y 56. El conquistador Hernán Cortes pidió en sus disposiciones testamentarias, otorgado en Sevilla el 11 de Octubre de 1547, que la administración del hospital de la Limpia Concepción que fundó en México en 1521 fuese como el del hospital de las Cinco Llagas de Sevilla: "Mando que en la administración y gobernación del hospital de Nuestra Señora de la Concepción que yo mande hacer en México, se guarden las que tiene el hospital de las Cinco Llagas de esta ciudad de Sevilla".

13 M. Ortega López, Op. cit., p.332. La criada trabajaba en una casa a cambio de techo, comida, ropa, cuidados en caso de enfermedad y una dote matrimonial.

14 P.E. Rivasplata Varillas. Aproximación histórica de la enfermería femenina en Europa y América. La enfermeria en el hospital de las Cinco Llagas de Sevilla y los hospitales de Lima en el XVIII y parte del XIX. Berlín: Editorial Académica Española, 2012, pp.116-119. 
clave para alcanzar la salvación. A partir de ese siglo proliferaron libros sobre el tema. ${ }^{15}$ En un comienzo se creía que se entablaba una lucha final en el momento de fallecer para luego suavizarse en el XVI, con Erasmo de Rotterdam, cuando el arte de bien morir se orientó a bien vivir para tener una buena muerte. ${ }^{16} \mathrm{El}$ Concilio de Trento buscó que la vida terrenal fuese una preparación continua para la muerte para lograr una corta estadía en el temido Purgatorio y alcanzar la gloria eterna. ${ }^{17}$ El bien morir no se podía hacer solo, a pesar de que la muerte es uno de los hechos más personales e individuales en la vida de toda persona. Se requería de la ayuda de especialistas en el tema como curas, pero éstos no eran suficientes, por eso surgieron personas que se dedicaron a acompañar al moribundo o al difunto hasta que fuese enterrado. El proceso de la muerte era un tiempo valiosísimo para arrepentirse, confesar los pecados y las debilidades del cuerpo, así como mantenerse firme a la fe ante el miedo y el dolor de la agonía. ${ }^{18}$ Por eso, se temía la muerte intempestiva en la Edad Moderna porque no daba tiempo para la contrición y exigía una vida la más correcta posible. Pero, también se consideraba mala muerte la larga agonía, en la que el enfermo no estaba plenamente consciente de sus actos ni de sí mismo. Sin lugar a dudas, según las ideas del momento, una buena vida cristiana sería la que aseguraría una buena muerte, pero como el ser humano pecaba constantemente, la gracia plena era inalcanzable para todos, por lo que un tiempo de contrición y arrepentimiento era necesario. ${ }^{19}$

Después del Concilio de Trento, la tensión que se puso en la idea del Purgatorio y en las manifestaciones externas de religiosidad ante la muerte en las mandas

15 R. Schmidt. "La praxis y la parodia del discurso del ars moriendi en el Quijote de 1615", en Anales Cervantinos, Vol. XLII, pp. 117-130, 2010, p. 1. El más famoso de todos los libros medievales de buen morir fue De scientia mortis del teólogo Juan Gerson en 1403 e indicaba que cualquier cristiano fuese laico o clérigo podía asistir a los moribundos en la hora de la muerte.

16 D. Erasmus. Preparación y aparejo para bien morir. Madrid: Fundación Universitaria Española, 2000, pp. 24 y 209-293. Erasmo recomienda las lecturas del Antiguo y Nuevo testamento y deja de lado las interrogaciones, las plegarias y las exhortaciones. Su única autoridad eran las Escrituras.

17 J. Le Goff. El Nacimiento del Purgatorio. Madrid: Editorial Taurus, 1989, p. 57. Según este historiador, en el siglo XIII se generalizó la idea del Purgatorio, aunque la idea cobraría forma desde el siglo XI; A.L. Haindl Ugarte. "La muerte en la Edad Media", en Revistas electrónica Historias del Orbis terrarum. No1, Santiago, 2009, p. 153; I. Adeva Martín. "Ars bene moriendi: la muerte amiga", en Ante la muerte: actitudes, espacios y formas en la España medieval. Pamplona: Ediciones Universidad de Navarra, 2002, pp. 295-360.

18 A. Morel d'Arleux. "Los tratados de preparación a la muerte: aproximación metodológica", en AISO. Actas II (1990), pp. 728-729. Después de Trento, para obtener la salvación eterna había que practicar asiduamente la confesión, la comunión y recurrir a la administración del viatico y la extremaunción que antes estaban reservados casi exclusivamente al clero.

19 P. García Hinojosa. Simbolismo, religiosidad y ritual barroco. La muerte en Teruel en el siglo XVII. Tesis doctoral de la Universidad de Zaragoza. Departamento de Historia Moderna y Contemporánea. 2010, p. 46. 
testamentarias aumentó y con ella las indulgencias y las obras pías. ${ }^{20}$ Se buscaba el bien morir en todos los asuntos terrenales y celestiales, es decir, que estuviesen arreglados o al menos encaminados para poder alcanzar el cielo sin problemas, para lo cual se estableció un pacto entre vivos y muertos en el que los primeros se cuidarían de rezar por las almas de los difuntos y éstos delegarían sus bienes a cambio de eso. ${ }^{21}$ La administración de la muerte la llevó a cabo la Iglesia desde la extremaunción, celebración de funerales, enterramientos, misas e indulgencias. El Concilio de Trento impulso la confesión y la aplicación del sacramento de la penitencia. $^{22}$

En la Edad Moderna castellana el bien morir se convirtió en una práctica tan extendida que se necesitaron de muchos guardianes o vigilantes de la muerte para identificarla y encaminarla. El médico era el que la anunciaba y con esto terminaba su trabajo para cederla a los sacerdotes y las personas encargadas del bien morir.

\section{La Madre agonizante}

En el siglo XVI, el bien morir de las enfermas en el hospital de las Cinco Llagas de Sevilla fue llevado a cabo por el cura, acompañado por la madre mayor, también conocida como madre de llaves, la madre enfermera o madre cirujana, según la sala donde las enfermas estuviesen alojadas. ${ }^{23}$ Sin embargo, la experiencia había enseńado que era necesario la privacidad para llevar a cabo este duro trance, por lo que, poco a poco las agonizantes fueron concentradas en la parte central de la sección de enfermería femenina, denominada la Sala de San Pablo, que era el área más antigua del hospital. ${ }^{24}$

20 M. J. García Martínez. Cuidar el cuerpo y salvar las almas. La práctica de la enfermería según el modelo de la congregación de enfermeros obregones. Tesis defendida en la Facultad de Geografía e Historia de la Universidad de Sevilla el 20 de abril del 2007, p. 120. En la Espańa del siglo XVI, la vivencia de la enfermedad y la muerte se caracterizaba por su extrema religiosidad, aumentado aún más desde el Concilio de Trento. A. Domínguez Ortiz. España. Tres milenios de historia. Madrid: Marcial Pons, 2007, pp. 231-232. En España se vivía una verdadera cultura de la muerte en los siglos XVI y XVII; S. Gómez Navarro. Op. cit., pp. 16-17. El auge de la muerte barroca fue entre 1580 y 1660.

21 A. Morel d'Arleux. Op, cit., p.729. Después de Trento, se abandonó la idea del buen vivir de los reformistas para regresar al arte del buen morir. La iglesia ejerció el control espiritual y corporal de sus fieles y aún el control económico a través de los testamentos.

22 J. Burriera Sánchez. "Los jesuitas: De las postrimerías a la muerte ejemplar", en Hispania Sacra, LXI, 124, Julio-Diciembre, 2009, pp. 513-544.

23 F.J. Lorenzo Pinar. Muerte y ritual en la Edad Moderna, Salamanca: Universidad de Salamanca, 1991, p.41. La Iglesia había transmitido una idea que asociaba la enfermedad con una advertencia previa sobre la fragilidad de la vida, y por tanto la ligaba a la necesidad de preparación para bien morir.

24 G. Vigarello. Lo Sano y lo Malsano. Historia de las prácticas de la salud desde la Edad Media a nuestros días. Madrid: Abada editores, 2006, pp. 85 y 304-305. A partir del XVI surgió una piedad 
No hay que pasar por alto que la finalidad de este hospital como cualquier otro de comienzos del Quinientos era el proceso de bien morir de la enferma. Pronto, los administradores se dieron cuenta que eran insuficientes los curas para esta tarea, entonces otras personas externas al hospital fueron necesarias. En 1528 se dio el caso de una donada que trabajó en todas las ocupaciones, incluso en el área de agonizantes del hospital estudiado. Al fallecer, dejó sus bienes para pagar anualmente a las mujeres que servían a las enfermas del Hospital de las Bubas de Sevilla. ${ }^{25}$ Un ejemplo de confraternidad y solidaridad entre mujeres de entroncada fe religiosa que seguían los mismos objetivos.

En el hospital de las Cinco Llagas, la madre agonizante surgió en el siglo XVII, en forma tardía. Esta madre no aparece mencionada en las dos primeras constituciones del hospital de 1503 y 1603, pero sí en la de 1624. Sin embargo, debió aparecer años antes, pero se formalizó en dicho año. La última constitución mencionada indica que la madre agonizante tenía que ser una mujer con virtudes especiales para desarrollar tal ministerio porque la que se encargase de este oficio tenía que poseer características intrínsecas especiales que tocaran la beatería. Al menos así fue a comienzos del siglo XVII, ya que significaba el contacto cotidiano con la muerte. Esta ocupación exigía mucha responsabilidad y templanza. ${ }^{26}$ Sus obligaciones eran ayudar al bien morir de las enfermas, asistir a las enfermas desde que el médico o cirujano dispusiere darles el Santo Oleo. ${ }^{27}$ Su deber era no apartarse de la agonizante, animándola y consolándola con plegarias leídas a

más cotidiana, una vigilancia que debería alcanzar todos los momentos de la vida. Un sentimiento más agudo de lo inestable... diluida en la diversidad de los momentos, la intensidad de la última hora tiende a perder algo de su fuerza... la muerte se habia hecho menos temible y menos amenazador. F.J. Lorenzo Pinar. Op. cit., p.63. El instante mismo de la muerte jugaba un papel decisorio en la mentalidad de la época en el terreno de la salvación, el arrepentimiento. La muerte sin padecimientos y corta, sin ser repentina, era propia de los justos.

25 Una donada era una mujer seglar que se retiraba a los monasterios o casas de religión para servir a Dios y a los enfermos. ADPS. Libro de "recibo y gasto", f. 106. Ya en 1546, el Hospital de la Sangre pagaba al mayordomo del Hospital de las Bubas una donación de 600 maravedíes anuales a nombre de la madre donada que murió en el Hospital de la Sangre. El capital era unas casas que había dado a este hospital del cual obtenía la mencionad renta que se continuaba dando en 1567.

26 B. Bosh de Centellas y Cardona, 1645-1714. Prácticas de visitar los enfermos y ayudar a bien morir. En Madrid, en la imprenta de francisco de Villa-Diego, 1713, p. 3. Los que ayudaban a buen morir se les consideraba colaboradores de Dios porque libraban a los agonizantes de los engaños de satanás por el santo aviso de quien la asiste, dándolas a Dios que los crio para el cielo. Por eso, se honra a los celadores del bien de las almas con el titulo de coadjutores de Dios.

27 Anónimo. Arte del bien morir y breve confesionario (1479-1484). Palma de Mallorca: Olańeta, 1999. El que conducía el buen morir, tenía que asegurarse que el moribundo creía los artículos de fe según indicaba la Iglesia. También lograr que el agonizante se arrepintiese de sus pecados y que perdonase a los que le habían ofendido y pidiese perdón a los que había injuriado. Era necesario que el moribundo reconociera y creyera que Jesucristo había muerto por la salvación de la humanidad y que de otra manera no hubieran sido posible, sino sólo por mérito de su Pasión, por lo cual debía dar gracias a Dios. 
cualquier hora y llamar al cura que fuese semanero si alguna enferma se quisiese confesar a cualquier hora del día o de la noche. ${ }^{28}$ También, se ocupaba de remendar la ropa o cualquier otra tarea que la madre mayor le asignase. Aunque la labor de la madre agonizante no se constata en los libros, legajos ni inventarios de comienzos del siglo XVII, sin embargo su importancia se hizo evidente y escaló rápidamente la consideración que se le tenía por la necesidad de acompañamiento permanente a las moribundas. Su importancia se hizo vital cuando creció la obsesión por alcanzar una buena muerte en un lugar donde se presentaba en cualquier momento y había que estar vigilante para que ninguna enferma muriese sin estar oleada y bendecida. ${ }^{29}$

El hospital de las Cinco Llagas recibía jóvenes pobres para que trabajasen en el hospital a cambio de un salario y una dote para tomar estado de casada. ${ }^{30}$ Estas jóvenes no se habrían utilizado en el área de agonizantes, según las constituciones de 1634 y 1734 , quizá porque no era una ocupación que cualquier persona pudiese realizar. Sin embargo, aunque los reglamentos no lo consignasen la realidad se impuso, recibiéndose algunas doncellas de dote porque el trabajo que se realizaba en el área de agonizantes era superior a las fuerzas de una sola madre agonizante. Esto se aprecia y comprueba en el libro inventario del Hospital de las Cinco Llagas donde aparecen camas para las doncellas en 1636, 1699, 1725 y $1726 .{ }^{31}$

La primera madre que llevó el título de "agonizante” apareció en 1608 y fue aumentando su número progresivamente. Así, a mediados del siglo XVIII ya había dos e incluso tres. La evolución de las madres agonizantes se puede dividir en cuatro periodos, cada uno con sus propias características:

1) El periodo comprendido entre 1608 a 1627 fue ocupado por las llamadas "madres que ayudaban a buen morir". En total, fueron seis o siete beatas. ${ }^{32}$

28 BC. La constitución de 1734 sobre las madres agonizantes. No 113 y acuerdo de 1729, f.100 r; B. Bosh de Centellas y Cardona, 1645-1714. Prácticas de visitar los enfermos y ayudar a bien morir. Madrid por la viuda de Barco López, 1807, p. 8. El que se dedica a buen morir debe ser una persona limpia de pecado y debe procurar con todo cuidado limpiar su conciencia a través de la confesión y ponerse bien con el señor quien en este ministerio quiere servirle. De cuya disposición y pureza de la propia conciencia procede el celo más fervoroso, el despreciar los frios de un invierno, los calores de un verano, la falta de dormir y otras muchas incomodidades que trae consigo la continua vigilancia con que día y noche ha de estar el ánimo pronto a esta obra; L. Scupoli. Combate espiritual. Madrid, en la imprenta de Joseph Doblado, 1771, Parte segunda, pp.274-279, p. 3 y 173. Tres cosas eran necesarias para el soldado de Cristo. Animo grande y resuelto a pelear sin desanimar. Valor para conseguirlo y fe. Las armas para esta guerra son estas dos resistencia y violencia. Que para pelear bien debe el soldado de Cristo huir con toda cuidado las tribulaciones, e inquietudes del corazón.

29 D. L. González Lopo. "El ritual de la muerte barroca. La hagiografía como paradigma del buen morir cristiano", en Ciencias sociais e humanidades, SEMATA, 2006, vol.17, pp. 299- 320.

30 P. E. Rivasplata Varillas. Las doncellas de dote del hospital de las Cinco Llagas de Sevilla. Una lectura en clave de género. Berlín: Editorial Académica Española, 2011, pp. 25-80.

31 ADPS. Legajo 1. Inventarios del hospital de las Cinco Llagas 1699,1725 y 1726.

32 Ingresaron algunas beatas que mantenían ideales mendicantes, realizaban tareas asistenciales 
En este lapso de tiempo, esta función fue desempeñada por una sola mujer que dejaba el cargo al fallecer. Este periodo se inauguró con una anciana y terminó con una joven. Esto significaría que se tuvo que relegar la experiencia por el vigor y dinamismo que se requeriría para atender a tantas moribundas. Cada una ganaba catorce reales al mes, el mismo salario que recibía una doncella de dote o aprendiz. Estas mujeres sabían leer y algunas de las primeras pudieron haber sido hidalgas viudas que dedicaron los últimos años de sus vidas a realizar esta labor pía tan necesaria para ellas. ${ }^{33}$

La primera mujer que ayudó a buen morir fue la beata María de Santa Ana que ejerció de 1608 a 1618. En la junta capitular de 1608, los patronos del hospital pidieron que se recibieran dos mujeres, una de ellas anciana, de "vida y hábito honesto", para que ayudase a bien morir a las enfermas, dándosele ración y salario. ${ }^{34}$ La documentación nos devela el nombre de una de ellas, la beata María de Santa Ana a quien pagaban catorce reales por mes. ${ }^{35}$ Petronila de Santa Ana le sucedió en el cargo por sólo un año para ser sustituida después de dos años por María de Jesús que trabajó de 1622 a 1626. Ambas fallecieron en el cargo. Francisca de Jesús laboró por un año y María de la Encarnación estuvo de febrero a mediados de marzo de 1628 cuando enfermó gravemente y fue sustituida por una joven que había ingresado al hospital como doncella de dote llamada María de los Santos desde junio de 1628 y se convirtió en la nueva madre del buen morir, permaneciendo en tal cargo por seis ańos y medio hasta 1635 cuando falleció. Este primer periodo se caracterizó por la alta mortalidad de las encargadas del buen morir debido a la cercana exposición a las agonizantes que terminaban contagiándose y por el exceso de trabajo para ser ejercida por mujeres de avanzada edad.

2) En el siguiente periodo comprendido entre 1636 a 1658, el cargo fue desempeñado no sólo por beatas, sino por viudas, solteras y algunas casadas cuyos

y una actividad religiosa muy intensa, dedicadas a las oraciones y asistir a los agonizantes; S. Pérez González, La mujer en la Sevilla de finales de la edad media. Solteras, casadas y vírgenes consagradas. Sevilla: Universidad de Sevilla, Ateneo de Sevilla, 2005, p.133. Esta historiadora en el Archivo de Protocolos de Sevilla detectó a una beata del hospital de la Misericordia, llamada Ana Fernández, entre los años 1441 y 1504 .

33 J. B. Poza (S.I.) 1588-1659. Practica de ayudar a bien morir. Madrid: Melchor Sánchez, a costa de Gabriel de León, 1657, fol.1. En los libros de bien morir había sacramentos de confesión, comunión y extremaunción. Actos de contrición, agradecimiento, resignación, las oraciones de santos y escrituras. Oraciones y otros motivos para amar, para esperar a Cristo y para avivar la fe por medio del sacramento; L. Scupoli. Op.cit., pp.274-279. En este libro había dos capítulos. Uno sobre el modo de armar al enfermo para la batalla, que ha de tener con el enemigo de solo a solo. Y el otro sobre el modo de armarse para vencer las tentaciones contra la fe.

34 ADPS. Legajo 4A. Libro de autos capitulares. Empieza en junta de 4 de mayo de 1584 a 10 de octubre de 1635 , f. 75 v (1608).

35 ADPS. Legajo 112. Libro de recibo y gasto de 1608, f.63 r (1608). 
esposos estaban ausentes. Estas mujeres empezaron a ser conocidas como "madres agonizantes". La experiencia del periodo anterior indicaba que era necesario mujeres jóvenes y de mediana edad para ejercer el cargo. Siguieron ganando catorce reales mensuales. La primera de este periodo fue María de Pedroza que también había sido doncella de dote, habiendo ingresado como tal en 1629 para luego ejercer el cargo de agonizante de 1636 a $1640 .{ }^{36}$ Es decir, se repitió la experiencia que cerró el ciclo anterior, dar el cargo a mujeres jóvenes con fuerte inclinación religiosa, capaces de renunciar a sus dotes para continuar en el hospital. De 1640 a 1644 asumió el cargo Catalina Clavero, siendo reemplazada al enfermar en 1642 por Andrea de la Trinidad. Esta mujer fue sustituida por María de Jesús de 1645 a 1648 y se convirtió en una de las víctimas de la peste de 1649. En ese cruento año casi todos los religiosos del hospital ejercieron el cargo de bien morir y la consecuencia fue la muerte del administrador, secretario notario y los dos curas. La madre de buen morir de ese año fue Isabel de María que sobrevivió y se mantuvo hasta 1650. Después de la peste, no se hicieron uso de madres agonizantes hasta 1658 porque había descendido el número de enfermas, cuyas necesidades espirituales fueron satisfechas por los curas del hospital. Sólo hubo una madre agonizante llamada Isabel de Medina en el año de 1655.

En este periodo, todo hace indicar que existía una relación directa con el área de incurables porque estas enfermas eran atendidas por una madre de agonizantes. Las incurables casi no recibían atención médica y los esfuerzos estaban dirigidos a la preparación para la muerte. Por esta razón, algunas madres de agonizantes recibieron su salario del área de incurables desde 1620 y lo pagaba el patronato que fundó dońa María de Torres, mujer del jurado Gaspar de Ávila Alvasajado. ${ }^{37}$ El hospital se hizo cargo del salario de esta madre agonizante desde 1658:

"Mandaron que la plaza de madre agonizante que hoy hay en este hospital y corre por cuenta de una cama de incurable corra de aqui adelante por cuenta del Hospital de la Sangre y se le dé ración media hogaza de pan y la carne que se da a una hija de las que sirven dicho hospital y doce reales de salario cada mes". 38

36 ADPS. Legajo 4B. Libro de juntas patronales (1637-1658), f.28 r. María Pedrosa se le dio gratificación o ayuda de costa de cien reales en 1638.

37 ADPS. Legajo 4B. Libro de juntas capitulares de 1616 a 1637, f. 21 r-v, f.23 r-v, f.14 r. (1620). El área de incurables se fundó con veinte camas en 1620. Esta sección recibió veinte mil ducados.

38 ADPS. Libro de juntas o actas capitulares de patronos del hospital de las Cinco Llagas.1637-1658, f.237 v (1658). 
Llama la atención que no fuese tratada como una madre, tal como la constitución de 1624 la denominaba, sino como una hija de dote con un salario inferior a la de una madre. A pesar de ser madre, no recibió salario de una hasta 1663:

"Mandaron que a la madre que sirve y sirviere de aqui en adelante la plaza de agonizante se le dé la misma ración y salario que le da a cualquiera de las otras madres". 39

3) El periodo de 1659 a 1683 se caracterizó por madres agonizantes que estuvieron muy poco tiempo en el cargo, meses, casi ninguna llegó al año, con grandes vacíos que serían cumplidos por las oficiales enfermeras de cada sala del hospital: madres enfermeras, cirujanas y convalecientes. No se encontraban mujeres idóneas para el cargo y eran rotadas o despedidas rápidamente. Se trataba de mujeres que trabajaban para subsistir sin mucho sentido religioso. Se trató de un periodo de inestabilidad en el cargo y ya se les había reducido el salario a doce reales mensuales. Este periodo la inauguró María de Herrera, seguida de Juana Baptista que trabajó tres meses para pasar a la sala de convalecientes. Asimismo, Inés de Jesús trabajó cuatro meses, Mariana de Arenilla, tres meses, Ana de San Joseph, tres meses en un lapso de cuatro años, entre 1660 a 1663. En 1664, María de Castañeda trabajó ocho meses y María de Jesús, cuatro meses. Lo mismo sucedió el año siguiente, María de Jesús trabajó diez meses y Josepha de León, dos. En 1666 entró Josepha de León por tres meses, Catalina Aguirre por dos meses y Juana de Torres completó ese año. A partir de 1667, empezó a estabilizarse la situación con Juana de Castro que trabajó todo el año. Dionisia de Carmona se mantuvo en el cargo por once años, de 1669 a 1680. Incluso se aumentó su salario como incentivo a catorce reales al mes desde 1677 y al enfermar fue reemplazada por Beatriz Camacho por cinco meses en 1675, una tal denominada "dońa Leonor" por seis meses en 1676 y por Antonia de Amesquita en diferentes meses de 1677 a 1679 . Las madres que siguieron permanecieron algunos ańos en el cargo, como Graciela María desde abril de 1680 a fines de 1682 y Juana Hidalgo desde agosto de 1682 a fines de 1683. Finalmente, la madre agonizante María de Alarcón permaneció en el cargo por nueve años, de 1684 a 1692, y durante este tiempo fue reemplazada cuando enfermó por María de Páez. Fue la única madre

39 ADPS. Legajo 4B. Libro de juntas o actas capitulares de patronos del hospital de las Cinco Llagas (1659-1687), f.59 v (1663) En 1663, se hace mención que a la madre agonizante se le debía dar la misma ración y salario que las otras madres. Esto indicaría que no tenía el mismo tratamiento hasta entonces que las demás madres; P.E. Rivasplata Varillas, Paula Ermila. Doncellas de dote del hospital de las Cinco Llagas de Sevilla..., pp. 1-345. Las doncellas de dote eran jóvenes que ingresaban a trabajar en el hospital por un salario, comida y sobre todo por una dote, cuyo nombramiento obtenían si permanecían en el hospital por tres años y posteriormente se casaban. Aparecieron en 1587. Estas jóvenes ayudaban en el trabajo a las mujeres responsables de cada área del hospital. 
agonizante que los patronos del hospital jubilaron el 11 de febrero de 1693, recibiendo una cama donde permanecer hasta morir. Esta mujer solía comprar mucha ropa de las enfermas fallecidas en las almonedas del hospital. ${ }^{40}$

Acordaron y mandaron que María Alarcón, madre agonizante, que de presente es de este hospital se le dé la primera cama de incurables que vacare en él sin que para ello sea necesario consultar al Sr. patrono a quien toca, tocare su provisión porque desde ahora para cuando llegue el caso dicha vacante hacian e hicieren nombramiento en la dicha María de Alarcón en la dicha cama de incurable por contar a dichos Srs. de su falta de salud y del mucho tiempo que ha estado sirviendo en el hospital." 41

4) En el periodo de 1693 a 1728 hubo sólo dos madres agonizantes que permanecieron años en sus cargos, las demás de uno a dos años. No hubo ninguna beata, trabajaban por el dinero y la comida que entregaba el hospital. Incluso, si no servían para el puesto, se les ponía en otro para darles la oportunidad de trabajar. Algunas de estas mujeres al comprobar que no servían para este trabajo ni para ningún otro que ofrecía el hospital, optaban por irse.

Durante las pestes, las madres agonizantes veían incrementar su trabajo y el peligro de muerte por contagio. Por ejemplo, Ursula de Castro le tocó asistir a las moribundas de la inundación de 1708 y la peste de 1709, quien entregó como limosna el salario de cuatro meses desde comienzos de noviembre de 1708 hasta fines de diciembre de dicho año (cincuenta y seis reales). Era tal la cantidad de enfermos en 1709 que tuvieron que atenderlos en los pasillos.

A comienzos del siglo XVIII, las madres agonizantes ya no eran necesariamente beatas y dedicadas absolutamente al bien morir, así que las rotaban en las otras áreas del hospital: convalecientes, cirugía, incurables, ropería, cocina y portería. Por ejemplo, la madre agonizante Margarita Polvorosa al comprobar su eficiencia en el trato con los enfermos se le orientó a madre de convalecientes. La madre Úrsula de Castro permaneció por mucho tiempo como madre agonizante en diferentes temporadas. Eran madres consideradas de suma confianza para desempeñar cualquier cargo, específicamente de contacto directo con la enferma.

La siguiente es la relación de las madres de este periodo:

- María Páez de la Cadena trabajó como madre ropera antes de ser madre agonizantes desde el 11-02-1693 a 14-05-1694

- María de Salas ejerció de madre agonizante de 23-03-1694 a 31-12-1694,

40 ADPS. Libro de recibo y gasto. Legajos 106, 107, 108 A, 108 B, 109 al 125

41 ADPS. Legajo 4B. Libro de juntas o actas capitulares de patronos del hospital de las Cinco Llagas (perg.) (1687-1715), f. 21 v (1690). 
pero "se despidió y se fue". ${ }^{42}$

- Catalina Solano o de la Cueva estuvo de 15-06-1696 a 07-07-1696 cuando murió, su sueldo sirvió para los gastos de su entierro.

- Beatriz de Coria estuvo de 17-07-1696 a 25-02-1700 cuando murió. ${ }^{43}$

- Margarita Polvorosa estuvo de 13-10-1699 a 01-01-1706 cuando fue traslada a la plaza de madre convaleciente

- Úrsula de Castro fue madre agonizante de 13-04-1705 a 15-11-1712.

- Ana María Díaz ejerció el cargo de 16-11-1712 a 16-01-1713.

- Úrsula de Castro regresó de 16-01-1713 a 1715. Marcela de Medina de 31-12-1716 a 13-09-1718. Ana de Ubaneja de 14-09-1718 a 16-04-1719. Inés Gutiérrez de 22-04-1719 de 21-08-1720. Florestina María García trabajó de 22-08-1720 a 05-04-1721.

- Juana del Castillo Coronel trabajó de 23-04-1721 a fines de 1725.

5) El periodo de 1726 a 1811 se caracterizó por la mayor afluencia de enfermas al hospital y la necesidad del buen morir obligó al hospital a tener dos madres agonizantes. En el siglo XVII, había en el hospital de las Cinco Llagas sólo una madre agonizante, pero paulatinamente se hizo menester de una más, pues no era suficiente para el oficio, teniendo que trabajar de día y de noche. En la Visita General de Abril de 1729 se determinó tener dos madres agonizantes, la segunda de las cuales se la requería para que remendase la ropa o acudiese a otras enfermerías que la madre mayor le asignase, cuando no estuviese ocupada, ayudando a bien morir a una enferma en la sala de San Pablo o agonizantes. La segunda madre agonizante quedó formalizada en la constitución de 1734 con el salario y ración que recibían las otras madres. ${ }^{44}$

En caso que una de las dos madres agonizantes enfermase suplía su falta la madre cirujana. Los patronos en junta de abril de 1729, reconocieron lo excelente enfermera agonizante que había sido Juana del Castillo Coronel cuando trabajó como tal entre 1721-1725, por lo que se solicitó su ayuda en la sala de San Pablo mientras fue madre cirujana " $y$ en caso de enfermar alguna de dichas dos madres agonizantes, supliría su falta la madre cirujana Juana del Castillo Coronel por constar a los patronos lo bien que ejerció dicho oficio cuando lo obtuvo". ${ }^{5}$

42 ADSP. Libro de salario, libro 188.

43 ADSP. Legajo 263. Testamentos. Se hizo una almoneda con su ropa el 26-07-1700. Mandó dinero a su sobrina y a su hermano y el restante para 88 misas por su alma.

44 ADPS. Legajo 4B. Autos capitulares de este hospital de la Sangre comienza ańo de 1716 y acaba ańo de 1734, f.100 r (1729). Las madres ganaban ciento sesenta y ocho reales de vellón anuales y ración diaria de vaca o pescado y pan blanco. En el siglo XVIII, había diez madres que trabajaban en la sección femenina de enfermería.

45 ADPS. Autos capitulares de este hospital de la Sangre comienza año de 1716 y acaba año de 1734. Legajo 4 B, f. 100 r (1729). 
Esta mujer desempeñó varios cargos en el hospital. Primero, fue madre cirujana de 1726 a 22-05-1730. Luego, madre enfermera de 1731 a 1736. En 1737, los patronos del hospital ordenaron que no viviera en el hospital mientras estuviese enferma, aunque le otorgaron una ración de comida diaria. Al cabo de unos ańos, se la encuentra como segunda madre agonizante desde 01-01-1744 para ascender a madre ayudante desde 15 de noviembre de 1747 a 1756 . Pidió amparo al hospital en 1763, pero se le denegó. No se saben los motivos.

Según Junta patronal de 1773, era costumbre de la madre agonizante llevar las velas y hacer vigilia por lo que trasnochaban. ${ }^{46}$ Dos eran las madres agonizantes que se turnaban en hacer la velación, la que hacía cada una por media noche, para vigilar a las enfermas y avisar al cura cuando estaban agonizando. ${ }^{47}$

En el siglo XVIII, se hizo tan necesaria esta ocupación que se tuvo la intención de nombrar a una tercera madre agonizante en $1787 .{ }^{48}$ No se pudo hacer realidad este designio por la mala situación que pasaba el hospital debido a las grandes inundaciones que sucedieron en Sevilla desde finales de 1783. Al final, quedaron sólo dos, a las que aumentaron cuatro reales más sobre los veintiséis reales de salario que tenía cada una.

Estas mujeres duraban muy poco en sus cargos por la que ninguna logró jubilarse y fueron las siguientes: (Tabla 1)

La madre agonizante superó a duras penas las consecuencias económicas provocadas por la desamortización de 1798 que significó disminución de dinero para el mantenimiento del hospital y pago de salarios. ${ }^{49}$ La desaparición abrupta de la madre agonizante se debió a la Guerra de Independencia española con el Primer Imperio Francés al instalar Napoleón en el trono español a su hermano José

46 ADPS. Legajo 4C. Libro de auto capitulares del hospital de la Sangre. Comienza año de 1764 a 1787, f.3 r y f. 51 v. Las dos mujeres se turnaban durante la noche y se caracterizaron por llevar una vela con ellas.

47 ADPS. Legajo 4B. Libro de Auto Capitulares del hospital de la Sangre, comienzo del año de 1764 a 1787, f.85 r (1777): “... que a la madre Elena Vasete se le dé ración completa de madre, y quede con la obligación de hacer la velación solamente con las agonizantes, la que hará cada una por media noche"

48 ADPS. Legajo 4B. Libro de Auto Capitulares del hospital de la Sangre, comienzo del año de 1764 a 1787, f.150 r (1787); M. Palacios Alcalde. "Formas marginales de trabajo femenino en la Andalucía Moderna", en Matilla, M. y Ortega, M. (eds.), El trabajo de las mujeres: siglos XVI- XX. Madrid, Universidad Autónoma de Madrid, 1996: 71-88. Las procesadas por delito de hechicería y curanderas solían servir cinco años en el hospital que se señalare. A veces iban procesadas por prácticas de alumbradismo. Así, la costumbre de ver a las viejas hechiceras trabajando como hospitaleras, parece haberse convertido en un tópico. El hospital estudiado no recibió ninguna procesada de la inquisición para que sirviese, como si lo recibían otros hospitales. Aunque si recibió una rea de la inquisición enferma a fines del XVIII.

49C. López Alonso. Memoria introductoria en De la beneficencia al bienestar social. Cuatro siglos de acción social, Madrid, Siglo XXI, 1986, pág. 20. Carlos IV ordenó enajenar los bienes hospitalarios en 1798 . 
Tabla 1. Madres agonizantes del hospital de las Cinco Llagas (1726-1811)

\begin{tabular}{|l|}
\hline 19Madre agonizante \\
\hline Antonia María de la Rosa (2-12-1726)(8-03- \\
1727) \\
Luciana de Ota (01-06-1727) \\
Agustina Miño (20-05-1728) (14-07-1731). \\
Ana María Pérez (01-08-1731)(09-11-1731) \\
María Bernal (16-11-1731)(04-10-1736) \\
Lorenza de Salazar (04-10-1736)(27-03-1738) \\
María Gordillo (08-12-1738) (11-03-1739). \\
Murió en el cargo. \\
Antonia de Roa (12-03-1739)(22-04-1739) \\
Juana de Espinosa (22-04-1739)(10-05-1740) \\
Julia de Torres (14-05-1740)(17-01-1742) \\
Inés Sabino(27-02-1742)(09-08-1742) \\
María Bartolomé(12-08-1742)(26-08-1743)
\end{tabular}

María Benites (12-12-1743)(21-07-1744)

María de Carmona (23-07-1744)(14-10-1746)

María Basete (15-10-1746)(15-11-1747)

María Teresa Jiménez (23-11-1747)(20-10-

1749)

María Barreto (04-10-1749)(05-11-1749)

Ignacia de Jesús (14-11-1749)(13-12-1749)

Florencia de Alique (15-12-1749)(25-04- 1756)

Lorenza de Reina(29-04- 1756) (08-07-1756)

Josefa de Vargas(01-01-1757)(10-07-1762)

Petronila de Huelva (01-1-1763)(24-06-1764)

Josefa de Vargas ( 24-06-1764)(11-11-1764)

Brígida de Lara(11-11-1764)(21-06-1768)

Juana Moscoso (22-06-1768)(02-07-1769)

Josefa Rodríguez(17-09-1769)(05-06-1770)

Brígida de Lara (14-09-1770)(25-11-1772)

Juana Velasco (01-05-1773)(30-11-1782)

Varias madres agonizantes vacantes. Todo el

año de 1783

Rafaela Franco(1784-1790)

María Liñán (1791). Pasó a convalecientes Ana de Lara Continuó en agonizantes (1792 1796). Paso a incurables

María de (el secretario no terminó de completar su nombre) $1796-1809$

\section{2oMadre agonizante}

María Josefa de Ocampo (4-06-1729)(12-12-1729)

María de Flandes (15-01-1730)(21-05-1730)

Leonor Morales (05-10-1730) (01-04-1732)

María Bravo (29-03-1732)(12-31-1732)

María Teresa Pacheco (4-03-1732)(18-03-1732)

María Bravo (22-12-1733)(11-11-1735) murió.

María de Flandes(15-11-1735)(07-06-1739)

Catalina Arias (08-06-1739)(Dic-1739)

Gregoria Conde(14-02-1740)(07-04-1741)

Rosa Barredo(10-04-1741)(04-07-1743)

María Basete(06-07-1743)(25-04-1744)

Catalina de Soto(30-04-1744)(15-07-1745)

María Rosalia de Vargas Machuca

(16-07-1745)(07-01-1746)

Catalina de Soto (13-01-1745)(09-10-1746)

Juana Navarrete(22-10-1746)(26-07-1748)

Catalina Arias (30-07-1748)(juni-1750)

Plaza vacante (01-07-1750)(19-09-1750)

Mariana Mateos (21-12-1750)(15-05-1751)

María Farfan (24-05-1751)(14-03-1755)

María de Rueda (15-03-1755)(6-04-1755)

María Ortega (12-04-1755)(02-02-1757)

María Farfan (25-02-1757)(19-11-1758) murió

Teresa Otaudi (05-12-1758)(09-07-1759)

Antonia Gonzáles (24-10-1759)(12-12-1759). Murió.

María Matheos (01-01-1760)(16-07-1760)

María de Rivera (30-07-1760)(18-08-1760)

Catalina Sánchez (27-02-1761)(03-06-1761)

Juana Galindo(04-06-1761)

Rosa de Encinas (10-10-1761)(31-12-1761)

Petronila de Huelva (01-01-1762)(dic-1762)

María Márquez (01-01-1763)(11-05-1763)

Manuela Macias(07-07-1763)(29-07-1763)

Juana Moscoso(07-08-1763)(08-11-1764)

Fulgencia Núñez (22-11-1763)(08-03-1766)

Murió

Teresa Sarmiento(12-03-1766)(04-06-1766)

Murió.

Josefa de Taguas (09-03-1767)(31-03-1770)

Gertrudis de Molina(15-04-1770)(11-09-1771)

Damiana Villanueva(02-02-1772)(23-03-1772)

Florentina Navarro (01-11-1773)(31-12-1773)

Gertrudis de Molina (14-02-1774)(31-12-1774)

María de Ortega (07-01-1775)(04-09-1775)

María Rodríguez(10-04-1776)(31-12-1780)

Ana Luna(28-02-1782)(31-05-1783)

Leonor Romero(16-06-1783)(31-12-1783)

Ana Lara (1784- 1789)

Vicenta de los Santos ( 1789- Julio 1790)

Ana de Lara (1791) y Nicolasa de los Reyes (1791-1792).

Enferma por 5 meses la suplió varias vacantes.

Desde 1793 a fin de agosto 1809 . El secretario no escri-

bió los nombres de las madres

Fuente: Libro recibo y gasto (1691-1696). Legajo 125. Libros salarios. Legajos 187 y 188. 
Bonaparte que decretó el 18 de agosto de 1809 la supresión de todas las ordenes regulares, monacales, mendicantes y clericales, cuyos bienes pasaron a propiedad de la nación. ${ }^{50}$ De esta manera, el hospital de las Cinco Llagas se desligó temporalmente de la Iglesia para retornar en 1814 con el regreso de Fernando VII al trono, ${ }^{51}$ pero esta vez sin madres agonizantes.
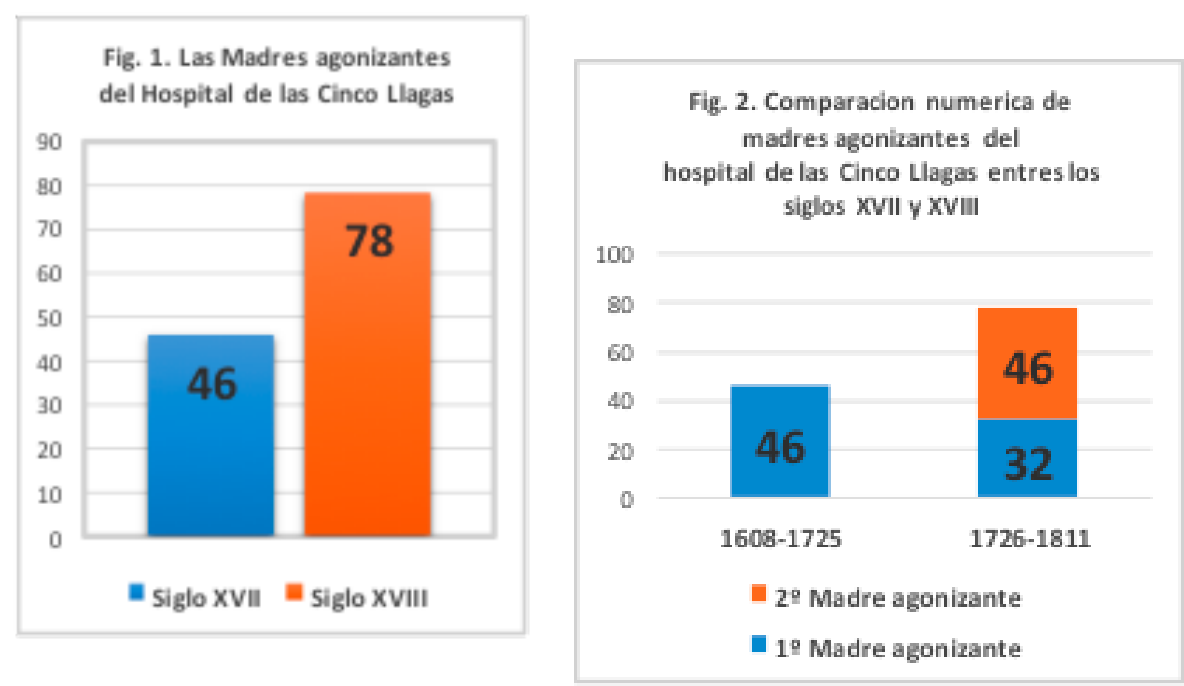

EL PROCESO DE LA MUERTE: DE LA ENFERMERÍA AL CAMPO SANTO O IGLESIA

El rito de la muerte en el Hospital de las Cinco Llagas de Sevilla fue llevado a cabo por el siguiente personal hospitalario: el médico, el cirujano, el cura semanero, la madre agonizante, los sacristanes y el administrador.

1. Orden de olear: El médico, el cirujano o el administrador

El médico era el que indicaba si la enferma debía ser oleada y preparada para la muerte. Vivía en el hospital y podía ser requerido en cualquier momento, pues sólo él podía dar la orden de realizar la extremaunción en el área de enfermería femenina. ${ }^{52}$ El cirujano lo determinaba en el área de cirugía. En caso de emergen-

50 S. Gómez Navarro. Op. cit., p. 23. Se llega a los 1800 en España sin que se registren síntomas alarmantes de descristianización o laicización francesas, al menos de forma absoluta. $\mathrm{Si}$ se producen cambios es por motivaciones económicas, sociales o culturales pero no irreligiosas o de descreimiento.

51 G. Rueda Hernanz. "La desamortización en España: un balance (1766-1924)", en Cuadernos de Historia, no 38, Madrid, Arco libros, 1997, pág. 78.

52 F. Martínez Gil. Muerte y sociedad en la España de los Austrias. Cuenca: Ediciones de la Universidad Castilla-La Mancha, 2000, pp. 366-369. La obligación del médico era no ocultar al enfermo la cercanía de la muerte para prepararse como convenía para alcanzar la vida eterna. $\mathrm{La}$ 
cia, si el médico o el cirujano no se encontraban en el hospital entonces la orden la emitía el administrador. El sacerdote comunicaba o advertía al enfermo con tiempo que iba a morir para que se preparase..$^{53}$

\section{Extremaunción: El cura semanero}

Los sacramentos del viático y extremaunción eran administrados por el cura semanero después de que el médico, cirujano o administrador lo dispusieran. Se mandaba llamar al cura a cualquier hora del día, o de la noche. ${ }^{54}$ Si no se le encontraba fácilmente, entonces se recurría a la campana para que se acercase a la enfermería de agonizantes. En caso de emergencia, lo podía administrar el cura que no era semanero. ${ }^{55}$

El administrador era sacerdote y autoridad principal del hospital. Uno de sus deberes era controlar que los curas hiciesen completos los sacramentos de la extremaunción y con la decencia debida, según disponía el manual Romano, de otra manera se caía en falta. El acto de la extremaunción consistía en el saludo, confesión e imposición de la penitencia. Si la enferma no estaba en condiciones para manifestar sus culpas, el cura le imponía alguna fórmula penitencial general. ${ }^{56}$ Formaba parte del ceremonial de la penitencia, las letanías de los santos, lectura de los siete salmos penitenciales, la recitación de la Fe, llamado el Símbolo y el Pater noster. ${ }^{57}$ El Símbolo era considerado como un ahuyentador del demonio y una tutela contra sus tentaciones. Se procedía a recitar salmos y letanías para estimular la contrición y a las unciones sacramentales que las ceremonias prece-

consciencia de la propia muerte era un signo del bien morir. La labor del médico termina al comunicar al enfermo la improbabilidad de su curación.

53 M. de Yebra. Op. cit, p. 160. El sacerdote estaba obligado de desengañar al enfermo y decirle con claridad del peligro en que estaba y de la proximidad de la muerte; P. Ariès. Historia de la muerte en Occidente. Desde la Edad Media hasta nuestros días. Barcelona, El acantilado, 2000, p.24. Normalmente el enfermo recibía una advertencia, pues la muerte súbita era excepcional.

54 L. Gómez Nieto. Ritos funerarios en el Madrid medieval. Madrid: Asociación cultural AlMudayna, 1991, p.51. La extremaunción se creía que ayudaba al moribundo a hacer una buena muerte fortaleciéndole contra los últimos asaltos del demonio.

55 F. Martínez Gil. "Del modelo medieval a la contrarreforma: la clericalización de la muerte", en Ante la muerte: actitudes, espacios y formas en la España medieval. Pamplona: Ediciones Universidad de Navarra, 2002, pp. 215-256. En la Edad Media el agonizante dirigía su muerte, en los siglos XVI y XVII el sacerdote se convirtió en la guía del proceso.

56 Poza, Juan Baptista (S.I.) 1588-1659. Practica de ayudar a bien morir. Madrid: Melchor Sánchez, a costa de Gabriel de León, 1657, folios 155r-183r. Buen morir de agonizantes presentes impedidos de los sentidos y agonizante ausentes. Oraciones de la Iglesia y de la Cartuja; M. de Yebra, Op.cit., p.137. Que no debe desamparar el sacerdote al enfermo aunque le vea que no habla, ni oye antes lo ha de asistir hasta que expire.

57 ADPS. Legajo 4B. Libro de juntas o actas capitulares de patronos del Hospital de las Cinco Llagas (1659-1687), f.82 v (1665). 
dentes habían servido de preparación. ${ }^{58}$ Se ungían los cinco sentidos, además el pecho, el corazón, los riñones, las espaldas, las junturas y especialmente la parte doliente del enfermo. ${ }^{59}$ Finalmente, se procedía a la realización del viático que es la eucaristía de los moribundos que según la creencia católica significa la ayuda segura en el paso de esta vida y la prenda cierta de la inmortalidad. ${ }^{60}$

El área de San Pablo o enfermería de agonizantes del hospital de las Cinco Llagas tenía, según los inventarios, veintidós cruces de madera a su disposición. ${ }^{61}$ Servía para colocarla delante de los ojos de la enferma próxima a morir. Así, el cura semanero, acercando el crucifijo, dirigía a la enferma oportunas palabras de aliento. Después de esta exhortación, la enferma besaba el crucifijo que quedaba colocado ante su vista. La cruz terminaba en la cabecera de la agonizante en señal de haber recibido el viático.

El cura tenía que percatarse que cada enferma tuviese la bula de la Santa Cruzada, pidiéndola al administrador si es que no lo tuviese, de modo que ninguna enferma muriese en el hospital sin tener la mencionada bula. El cura absolvía en virtud de las indulgencias de la bula. El cura debía utilizar una sobrepelliz para la administración de los sacramentos en enfermería, entierros y misas cantadas. ${ }^{62}$ Desde 1725, el cura semanero llevaba colgado en el cuello la llave del sagrario para la más pronta administración de la eucaristía.

Una de las obligaciones de la madre agonizante era ayudar al cura a preparar la extremaunción, colocando delante de la cama de la agonizante una mesa con un crucifijo encima, el aceite con agua bendita e hisopo y una vela encendida. ${ }^{63}$

58 J. A. Rivas Alvarez. Miedoy piedad: testamentos sevillanosdel siglo XVIII.Sevilla: Diptuacion provincial de Sevilla, 1986, p. 108. El muribundo tratara de recitar una letania. En la primera parte se reuga la intercesión de Dios y los principales santos, que le libre de una mala muerte, penas del infierno, del poder del diablo.

59 M. Righetti. Historia de la liturgia. Madrid: Editorial Católica, 1956, pp. 892-900.

60 J. A. Rivas Álvarez. Miedo y Piedad: testamentos sevillanos del siglo XVIII. Diputación Provincial de Sevilla, 1986, p.107. En el viatico se rocía agua bendita en señal de remisión de los pecados y con el agua se hacia la señal de la cruz en la frente.

61 ADPS. Legajo 1. Inventarios del hospital de las Cinco Llagas 1699,1725 y 1726. F. Martínez Gil. Muerte y sociedad en la España de los Austrias ... Op, cit., p. 369. El trance a la muerte exigía consciencia plena de ello del enfermo y alejarlo de todo objeto de distracción como cuadros e incluso no tener la presencia de parientes más próximos para que emociones fuertes no distrajeran el ánimo del moribundo. La agonía se desarrollaría en un clima de intimidad del moribundo y su fe.

62 ADPS. Legajo 4B. Libro de juntas o actas capitulares de patronos del hospital de las Cinco Llagas (1687-1715), f.10 r (1688).

63 F. J. Lorenzo Pinar. Op. cit., p.46. Cada institución instituía su propio sistema de velas para acompañar al enfermo de día o noche. La misión de los veladores estaba centrada en aconsejar al doliente para que recibiese los santos sacramentos y ordenase su alma... rezarían letanías, oraciones, devociones y las nueve lecciones de difuntos con sus laúdes para ayudarle a bien morir, además de relatarle buenos ejemplos y vidas de santos. F. Martínez Gil. Muerte y sociedad en la España de los Austrias ...op, cit., p. 367. El que ayudaba a bien morir no podía interferir en la muerte del enfermo con signos de pena o dolor para que muriese consciente de ello y sin distracción alguna. 
3. Testamento: El cura semanero

El cura semanero realizaba el testamento y la memoria de bienes de la enferma. ${ }^{64}$ Además de cumplir con las obligaciones propias de su oficio, los curas tenían que instruir a las enfermas para la mejor disposición de sus conciencias. ${ }^{65}$ Los priores ordenaron que antes o después de la extremaunción, los curas debían advertir a las moribundas que hicieran testamento, declarando sus bienes si los tuvieran: "declaración, para beneficio de sus almas, dejándolas en todo a su libertad: cuyos testamentos o declaraciones se podrán otorgar ante dichos curas, asi por concesión apostólica, como por práctica inmemorial' ${ }^{66}$ Sin embargo, si alguna enferma quería otorgarlo ante escribano público o notario, no se le impedía, siempre y cuando se obtuviese licencia del administrador para su autorización y viniese a las horas permitidas en la mañana o tarde para que no incomodase al sosiego y tranquilidad de las otras enfermas y clausura del hospital. Este tipo de testamento se debía sacar copia para guardarlo en el archivo del hospital. ${ }^{67}$

Según las constituciones, las enfermas no estaban obligadas a dejar ni bienes ni caudal al hospital ni a ninguna persona dentro de ella, fuesen ministros o sirvientes. Se les advertía eso. Y si a algún miembro del hospital se le dejaba algún legado, o era nombrado por heredero o albacea, los patronos del hospital instaban que renunciase a tales concesiones. El único que podía ser albacea testamentario era el administrador, solo o acompañado. También se permitía, sin ninguna coacción, que si las tales testadoras voluntariamente nombraban al hospital por su heredero, o dejaban algún legado de sus bienes, se admitía con tal que no fuese en perjuicio de las rentas de otro particular.

La voluntad de las enfermas era respetada. Sin embargo, en los testamentos de las enfermas del Hospital de las Cinco Llagas se observa que la mayor parte de los bienes muebles e inmuebles eran destinados a rezos y misas por el alma de las testadoras, así como en el ritual de la vigilia y el entierro. ${ }^{68}$ Otra parte eran donaciones al hospital. En algunos casos se legaban los bienes a hijos, sobrinos

64 J. B. Poza (S.I.) 1588-1659. Practica de ayudar a bien morir. Madrid: Melchor Sánchez, a costa de Gabriel de León, 1657, folio 59. El testamento está incluido en uno de los pasos del buen morir y significa dar a cada uno lo que es suyo. Las deudas a los acreedores pagadas, la hacienda a los herederos, la limosna a los necesitados y los asuntos del alma saneados; B. Bosh de Centellas y Cardona. Op. cit. 1807, pp.27-30.

65 D. González Cruz y M.J. de la Lara Ródenas, "Actitudes ante la muerte en los hospitales sevillanos. El hospital de las Cinco Llagas (1700-1725)", en Religiosidad Popular. Vol. 2, 1989, pp. 273-308. El enfermo espera la hora de su muerte para dictar testamento, al mes de testar ha muerto el $90 \%$ de los testadores entre 1700-1725.

66 BC. Constitución de 1734 . Art. ${ }^{\circ} 19$ y Art. ${ }^{\circ} 117$.

67 BC. Constitución de 1734. Art.o 19 y Art. 117 aumentada. "Saca a tanto autorizado, para que se ponga en la secretaria, en caso de fallecer la testadora".

68 ADSP. Legajo 263. Testamentos. s/f. 
y otros familiares y personas. ${ }^{69} \mathrm{~A}$ veces, a pesar de declarar tener hijos, preferían nombrar como principal beneficiario de sus bienes a sus respectivas almas. Cualquier inconveniente era absuelto por el administrador, dando parte de sus actos al menos al padre patrono presidente del año, fuese de Santa María de la Cuevas, San Isidoro del Campo o San Jerónimo de la Buenavista. ${ }^{70}$

Los curas anotaban en un libro todas las personas que fallecían en el hospital, el día en que murieron y si fueron enterradas en la iglesia o en el campo santo, el día de otorgamiento del testamento y ante quien se hizo, generalmente, el cura semanero, la madre agonizante, la madre enfermera y la madre de convalecientes. La constitución indicaba que este libro tenía que ser escrito claramente y sin equivocación alguna.

Hasta mediados del siglo XVII, este libro se lo daban al patrono presidente para que examinara las cuentas y cumpliera con los testamentos y memorias en la junta capitular de enero de cada año. Sin embargo, ya desde 1636, el libro era entregado al administrador para que lo revisara e hiciera cumplir la voluntad de las difuntas, mandara cobrar los bienes de la memoria e hiciese almoneda de ellos, si era el caso. Una vez cumplido el testamento, se entregaba al secretario del hospital para que tomase razón de él en el libro de testamentos y notificara a los patrones en las juntas capitulares. ${ }^{71}$

Las enfermas solían dejar sus bienes a las personas que las atendían al morir, cura semanero, madres y doncellas, lo que se trató de controlar, canalizándolo hacia misas para que los últimos beneficiarios fuesen los religiosos del hospital (priores, administrador, secretario, mayordomo y curas) quienes rezaban por las almas de los difuntos. Ya a mediados del siglo XVII, ningún enfermo o enferma que venía a curarse podía dejar bienes a ministros o criados del hospital.

69 ADPS. Legajo 4B. Libro de juntas o actas capitulares de patronos del hospital de las Cinco Llagas (1659-1687), f.106 v (1671). En este aspecto, a veces, se presentaban anomalías pues algunas moribundas al verse atendidas por las madres y doncellas les dejaban sus bienes bajo testamento. Esto fue prohibido terminantemente en 1671, pero algunas veces no pudieron evitarlo: “... que las doncellas que asisten a las enfermerias y las doncellas al servicio de los pobres de ninguna manera soliciten con las enfermas el que les den casa alguna ni lo tomen pues es constitución de este hospital y porque son informados de que a habido algún desorden en esto y es en descrédito del hospital, mandaron de que aqui en adelante no se haga tales cosas y que se cumpla la constitución y que el señor administrador se lo haga saber así con apercimiento que si lo contrario y dieren, se pondrá remedio en ello".

70 BC. Constitución de 1734. Const. 20 (corresponde a la const. ${ }^{\circ} 117$ en parte. Acuerdo de 1636, f. $125 \mathrm{v}$. Acuerdo de 1578, f.73 r.

71 ADPS. Legajo 4B. Libro capitular año 1636, f.125 r-v. Desde 1636, el cumplimiento de las voluntades de las enfermas pasaba por el cura semanero, administrador, secretario y finalmente el patrón anual del hospital. "Los patronos ordenaron que los curas del hospital en memorias y testamentos que hicieren las enfermas de la casa no puedan ser albaceas, sino que siempre lo sea el administrador del hospital sólo o acompañado para que de todo tenga noticia y que luego que se haga la memoria se le de cuenta de ello". 
Sin embargo, los ministros y sirvientes del hospital, al morir, podían dejarse cosas entre ellos en sus mandas testamentarias. ${ }^{72}$

Los testamentos y las memorias originales de las enfermas y de los trabajadores del hospital que otorgaban ante escribano o notario de fuera, los curas los entregaban al secretario del hospital para que hiciese legajo de los que ocurrieran cada año. ${ }^{73} \mathrm{Y}$ cosidos con sus rótulos, se ponían en el archivo y cuando se necesitaba sacar algún traslado o copia, el secretario se lo daba y autorizaba, como notario que era del hospital de las Cinco Llagas.

Las madres enfermeras generalmente dejaban sus bienes al hospital. Por ejemplo, en 1690, las hermanas Francisca y Josepha de Medina legaron un oficio de corredor de lonja en Sevilla a condición que el hospital se comprometiera a realizar algunas misas cantadas por sus almas y entregara una cantidad de dinero cada año a una pariente suya, heredando este oficio en su totalidad al morir la mencionada beneficiaria. ${ }^{74}$

A pesar que la norma indicaba que los libros de testamentos o memoria de enfermas y el libro de entierros estuviesen en el archivo del hospital, no se hacia porque el uso diario de ellos por los curas lo impedía. Los patrones determinaron en 1700 que se depositaran ambos libros en secretaria a causa de que los curas tenían estos libros maltratados y sin foliar, siendo información de suma importancia para la expedición de los certificados o fe de defunción. ${ }^{75}$ En cuanto al libro de testamentos, se deberían colocar en el margen la fecha de cumplimiento y el nombre de la persona que lo otorgaba y si murió o no, para no hacer cargo de estas voluntades en la junta de patrones.

Los curas podían hacer los testamentos en el hospital, sin que fuese necesario para que tuviese valor que asistiese un escribano público. Si la enferma sabía firmar, lo hacía y si no sabía, lo firmaba otro cura por ella. Los testigos solían ser las mujeres que la atendían al morir, pudiendo ser la madre enfermera, cirujana,

72 ADPS. Legajo 263. Memorias, testamentos, almonedas de bienes de difuntos, siglos XVIXVIII. En su testamento realizado en 1714, la madre incurable Andrea de Salazar dejó un collar engastado en plata, un barquito, una esterita y un pergamino de seda de Miguel Mañara que dio a la madre mayor. Lienzo de San Miguel a la madre incurable Antonia Falcón, dos pańuelos de estopilla, servilletas, bufetillo y cuadrito a la madre agonizante, una camisa, unas naguas blancas, una toalla a la madre enfermera, una esterita de esparto a la madre cirujana y un rosario a la madre ropera.

73 M.J. de Lara Ródenas, Op. cit. cap.5. Los escribanos acudían a los hospitales para poner por escrito las últimas voluntades de los enfermos allí ingresados, si bien fue usual en los hospitales lo hiciesen dictados al cura más antiguo del hospital.

74 ADPS. Legajo 4B. Libro de juntas o actas capitulares de patronos del hospital de las Cinco Llagas (1687-1715), f.20 v (1689) “... a condición que le pagasen 110 reales en cada año a María de la Encarnación por el tiempo de su vida, y después de dicha, la herede el hospital. Y que se les dijesen perpetuamente en la iglesia por seis curas seis misas cantadas con visperas y vestuarios y un responso sobre su sepultura en fin de cada misa. La primera en el Corpus y las cinco restantes en el Patrocinio..."

75 ADPS. Ibidem, f. 97 v (1700). 
agonizante, incurable o convaleciente. En sus testamentos indicaban el número de misas que mandaban decir y su limosna para que se pudiese tomar cuenta de ello. En caso que no indicase el número de misas, el producto de la almoneda de sus ropas lo determinaría.

\section{Bien morir: Madre agonizante}

La enferma oleada y sacramentada con la comunión del viático y la extremaunción y testamentada se entregaba al cuidado de la madre agonizante quien no se podía separar de ella ni de día ni de noche, pues no se podía dejar morir sola a la enferma por lo que las madres dormían y velaban en la habitación de agonizantes llamado San Pablo. ${ }^{76}$ La madre del bien morir no se podía separar de la moribunda, no la dejaba hasta que saliese de peligro o muriese, es decir, su deber era que la agonizante tuviese una agonía asistida. La madre agonizante tenía que reconfortar y exhortar a las enfermas a bien morir con jaculatorias, oraciones leídas y memorizadas. Era obligatorio que supiere leer para servirse de algunos rezos escritos para la ocasión. ${ }^{77}$ La madre agonizante debía adaptar la duración de las clausulas, invocación de los santos y de la Virgen a la agonizante que se dirigiese. Pero muchas veces se leía oraciones pequeńas en voz baja para no cansar a la agonizante. ${ }^{78}$

La madre agonizante tenía que estar pendiente que la enfermera estuviese tranquila y en paz en el crucial momento de morir y velar para que se cumpliera la tradición de tener una cruz y la bula de la Santa Cruzada. ${ }^{79}$ La enferma declarada agonizante y que había recibido la comunión por viático era señalada con una cruz debajo del número de su cama para que el cura las identificara. Una vez oleada se le ponía una cédula asida a la cruz, que lo expresara. Entonces, las madres agonizantes la asistían, en forma alternada, de día y de noche con sus velas. La muerte tenía que hacerse en compañía para reconfortar a la agonizante, pues en el

76 L. Gómez Nieto, Op. cit., p.51. Los que ayudaban a bien morir debían ser muy católicos, discretos y caritativos que ayuden cuando aún estuviese lucido a disponerse a morir, aconsejándole la redacción del testamento y la recepción de los últimos sacramentos.

77 G. Duby y M. Perrot Histoire des femmes en Occident. XVI- XVIII siecle. Paris: Perrin, Collection Tempus, Tomo III, 2002, pp. 382-283. T.Vinyoles, "Nacer y crecer en femenino: niñas y doncellas", en Historia de las mujeres en España y America Latina de la prehistoria a la edad Media. Madrid: Ediciones Cátedra, Vol. I, 2006, p. 490. Las primeras escuelas para niñas (no monjas) en España aparecieron a inicios del XVII, dando énfasis a la lectura y menos a la escritura. Escuelas para niñas para leer y escribir existieron en Flandes y París desde el siglo XIII y en Alemania desde el XVI por beguinas

78 J.B. Poza. Op. cit. F. 2V; J.Burriera Sánchez, Op. cit., pp. 520.

79 ADPS. Legajo 4B. Libro de juntas o actas capitulares de patronos del hospital de las Cinco Llagas (659-1687), f.182 r (1685). También, llamada "bula de moribunda" o "bula de difunta"; A.Morel d'Arleux. Op. cit., p. 729. Para reducir el tiempo en el purgatorio se adquiría bulas e indulgencias. 
Antiguo Régimen la muerte no era solitaria y tiene un carácter social. ${ }^{80}$ Por eso, se instaba en el hospital que todas las personas que estuviesen desocupadas y las enfermas convalecientes que tuviesen disposición para ello ayudasen a bien morir. ${ }^{81}$

Cuando alguna enferma fallecía, una de las madres agonizantes lo decía en voz alta para que todas las que estuviesen en la habitación de San Pablo encomendasen a Dios por su alma y se tañía una campana destinada a este fin para que todos lo supiesen y, también, rogaran por su ánima. ${ }^{82} \mathrm{El}$ morir en el hospital significaba obtener la absolución plena a los pecados, según la concesión otorgada en su fundación dada por el papado. ${ }^{83}$

\section{Amortajamiento: Madre agonizante}

Una vez que la enferma fallecía, las madres y doncellas de aquel cuarto sacaban su cuerpo y lo llevaban al amortajadero. ${ }^{84}$ Vestida de mortaja la ponían en el féretro, cubierto con el paño de difuntas. La fallecida estaba allí con velas hasta que pasado un tiempo regular era conducida al campo santo. ${ }^{85}$

$\mathrm{Al}$ retirarse el cuerpo de la difunta de la enfermería donde le había sorprendido la muerte - fuese en la sala de agonizantes (San Pablo), de cirugía (San Juan), de calenturas (San Pedro), de convalecientes y de incurables - se quitaba toda la ropa y cama y se ponía otra cama en su lugar.

En esta etapa, a veces, se hacían anatomías de cadáveres por los médicos o cirujanos previa licencia de los tres padres patronos, en presencia del administrador y del cura semanero. Sólo se hacían estas anatomías por causas urgentes.

80 J, Burrieda Sanchez Op. cit., p. 523. Los miembros de la casa debían entrar a ver morir a la agonizante, aunque unas pocas fuesen las que le cuidaran. Así el acompañamiento no sólo era con oraciones sino presencia física.

81 S. Gómez Navarro. Una elaboración cultural de la experiencia de morir. Córdoba: Servicio de publicaciones de la UCO, 1998, pp.69-73. La muerte no se hacía solo sino acompańado para cumplir el antagónico doble sentido de la muerte del Antiguo Régimen, a la par, publicidad y privacidad, colectividad e individualidad, pues se muere en comunidad, en familia, pero también se muere auténticamente solo.

82 F. Martínez Gil. Muerte y sociedad en la España de los Austrias ...Op, cit., p. 417. Para que todos recordaran que la muerte es un freno para no pecar; S. Gómez Navarro, Op. cit., p. 72. Repique de campanas avisaba a la comunidad de la muerte de uno de sus miembros para que se uniesen al esfuerzo que en ese momento se necesitaban de oraciones para la salvación de su alma.

83 ADPS. Legajo 1A. La Constitución de las Cinco Llagas de 1503.

84 S. Gómez Navarro, Op. cit., p. 77. Una buena muerte era el resultado final de una buena vida cristiana. Una prueba de buena muerte era tener la cara placida, flexible y natural como si aún la persona viviese.

85 J. A. Rivas Álvarez. Op. cit., p. 226. El hábito mortuorio más solicitado fue el de San Francisco en el siglo XVIII porque era depositario de indulgencias, protección, prestigio de la orden y la moda; S. Gómez Navarro, Op. cit., p. 73. La mortaja era una de los mejores escudos disponibles que pedía el moribundo para fortalecerse en el combate del purgatorio. Algunas enfermas pedían hábitos como el de San Francisco, del Carmen o de los Dolores 
Para evitar: "cualquier indecencia o escándalo que pueda resultar y desdoro contra el buen nombre y fama de las difuntas, a que son acreedoras con más fuerza, que estando vivas" ${ }^{86}$ Estas anatomías se hacían ocultamente, sin que las enfermas se enterasen. Si había discrepancia entre el médico y cirujano del hospital se nombraba otro médico que no perteneciese al hospital, al que se seguía y aceptaba su parecer.

6. Velación: Cura semanero, sacristanes, acompañantes

El cuerpo se velaba en el amortajadero, en el caso de las enfermas y en la iglesia, en el caso de ministros, madres enfermeras y otros. Esta diferencia dependía de factores económicos y del grado de autoridad dentro del hospital. Los curas daban la misa con sobrepellices, y los sacristanes cantaban en la iglesia durante la vigilia en la iglesia. Según los reglamentos del hospital, los curas realizaban una misa rezada de cuerpo presente por cada difunta. Los priores del hospital encargaban al administrador poner gran cuidado de que durante la velación hubiese personas que acompańasen al cadáver.

La mayoría de las enfermas eran muy pobres por lo que el hospital pagaba una misa por cada difunta. Sin embargo, algunas encomendaban misas pagadas por sus propios peculios. Por ejemplo, los testamentos de enfermas y los libros salarios de algunas mujeres que trabajaron en el hospital consignan el pago de misas, rezos y acompańamiento durante la vigilia y el entierro. Las difuntas dejaban indicado en sus respectivos testamentos el pago de misas y el número de las mismas. Las misas podían ser dichas por cualquier ministro eclesiástico del hospital desde el prior, administrador, secretario, mayordomo y curas. También, encargaban la compra de cirios y velas para rodear el cadáver hasta tres docenas para alumbrarlo las 24 horas de vigilia. Se solía alquilar un paño de terciopelo de difuntos y la caja, teniendo que pagar al costalero que traía ambas cosas. La misa de cuerpo presente estaba consignada en los testamentos en el que la asistencia se recompensada con la dádiva de limosnas, dos reales a costa del hospital y otros tantos por la misma difunta. ${ }^{87}$ El cura daba una vigilia en cada entierro por cada difunta o por dos o tres difuntas cuando se enterraban juntas, determinada según constitución de 1606 y junta patronal de 1613.

Las difuntas en sus testamentos describían como querían que fuesen veladas, homenajeadas y enterradas, a los que destinaban gran parte de sus ahorros. Designaban el hábito a vestir, las velas y velones a emplear y el número de acompañantes durante la velación de su cuerpo. ${ }^{88}$

86 BC. constitución de 1734 del hospital de las Cinco Llagas de Sevilla.

87 BC. Constitución de 1734. Acuerdo 1606, f. 56. Acuerdo 1613, f. 94 . Acuerdo 1672, f.106 v. Acuerdo 1724, f. 60 v.

88 F. Martínez Gil. Muerte y sociedad en la España de los Austrias ...Op, cit., pp. 382 y 387. La vela encendida significaba la luz de la fe. La demanda de los hábitos creció en el siglo XVI no sólo por motivos de devoción, sino por las indulgencias que aportaban. 
7. Entierro: Cura semanero, sacristanes, acompañantes

En los Quinientos, el entierro se hacía lo más cabalmente posible por el clérigo y el sacristán. Se podía enterrar de día o de noche. Si era de día se hacía la misa de réquiem cantada en cuerpo presente y si se enterraba en tiempos en que la misa no se podía decir, el Viernes Santo, entonces se postergaba al día siguiente con un responso sobre su sepultura con cruz y agua bendita ${ }^{89}$ Esto fue un pedido testamentario del Sr. Marqués Fadrique y Catalina de Ribera, su madre, fundadores del hospital. Se enterraban en el hospital las enfermas, así como los criados, ministros mayores y sus familiares. El cura semanero tenía por obligación asentar en el libro de difuntas de hospital para que constase y sirviese para la obtención de alguna fe o testimonio de su muerte que cualquier persona lo requiriese. ${ }^{90}$

Entierro en campo santo: Posteriormente a que el cura y los sacristanes terminaban la vigilia, el cuerpo era conducido de la iglesia o del amortajadero de la enfermería al campo santo, seguidos del cura semanero con sobrepelliz y estofa, y los sacristanes llevando la cruz y el agua bendita. ${ }^{91}$ El traslado del cuerpo desde el amortajadero se hacía bajo presencia del cura y sacristanes con cruz baja, de otra manera era considerado "contra la piedad" ${ }^{92}$ El portero y el caballerizo cargaban el ataúd, atravesando el patio de las Flores, ubicado entre la enfermería femenina y la enfermería de eclesiásticos hacia el campo santo, donde se le hacía el oficio de sepultura, y no se retiraban hasta quedar cubierto el cuerpo. ${ }^{93}$ Después de las misas y responsos necesarios, se enterraba a las difuntas teniendo la cruz alta y a velo, con canto y campana tañida. ${ }^{94}$

89 ADPS. Legajo 1A. La Constitución de las Cinco Llagas de 1503.

90 ADPS. Legajo 4B. Libro de juntas o actas capitulares de patronos del hospital de las Cinco Llagas (1637-1658), f. 227 v (1657).

91 ADPS. Legajo 4B. Libro de juntas o actas capitulares de patronos del hospital de las Cinco Llagas (1659-1687), f.108 r (1671). Se trató de imponer por costumbre que ambos curas fueran con sobrepelliz, llevando la cruz a la enfermería por la difunta, anunciados por las campanadas de la iglesia en 1671, pero imperó la costumbre que lo hiciera sólo el cura semanero, para que ambos curas pudiesen descansar.

92 ADPS. Legajo 4C. Libro de auto capitulares del hospital de la Sangre. Comienza año de 1764 a 1787, f.3 r: Existían cierta costumbre reprendida que mientras el cura y los sacristanes cantaban las vigilias, se trasladaba el cadáver a Campo Santo. Se hacían los oficios de sepultura con los responsos y solemnidad que indicaba el manual ritual romano. Se hacían los responsos con cruz alta sobre las sepulturas de las difuntas.

93 ADPS. Legajo 4B. Ibidem, f.107 r (1671): Retiraban el cuerpo del ataúd, que era utilizado sólo para el trasporte. Aunque muchas veces era trasportado sólo el cuerpo. “..suelen ir con el cuerpo y por no estar hecho el hoyo, lo dejan descubierto y no es razón hacerlo asi. Mandaron que primero se prevenga al enterrador abra el hoyo..."

94 S. Gómez Navarro. Op. cit., pp. 131-132. Cuando llega el cortejo fúnebre al lugar de la sepultura, vuelven a tocar las campanas para que se recuerde al difunto con rezos y por ese mismo motivo se hace entrega de dividas a los pobres e instituciones religiosas. 
La sepultura tenía que estar elegida antes que la difunta saliese del amortajadero, multando al que fuese omiso, o avisando a los priores del hospital en caso de no haber enmienda. El caballerizo tenía la función de abrir y cerrar las fosas en el campo santo. Se pagaba por el oficio de sepultura y la asistencia a cada uno de los curas veinticinco maravedíes por cuenta de la difunta y a cada sacristán que asistiese al oficio diez maravedies. El sacristán apuntaba las faltas que hubiese.

Entierro en la cripta de la iglesia: si, así, lo disponía la testadora y hubiese dejado caudal para ello, el administrador señalaba la sepultura y tasaba los derechos que había de percibir el hospital y ministros. No podía pasar de cien reales de vellón. ${ }^{95}$ Cantidad que no difería de cualquier entierro a personas de estratos inferiores, pues un funeral en estas condiciones costaba en Madrid en el siglo XVII hasta noventa y cuatro reales. ${ }^{96}$

La iglesia del Hospital de la Sangre tenía una amplia cripta en su subsuelo. Los personajes notables se enterraban debajo del altar y los ministros y madres enfermeras en los laterales de la iglesia. Ambos, en forma gratuita, pero los enfermos pagaban elevadas cantidades si querían enterrarse en la cripta. Las sepulturas en la iglesia estaban ubicadas desde la capilla de Nuestra Señora de Belén hacia el fondo porque no se podían enterrar cuerpo alguno desde el pilar donde se ponía el pulpito hasta el altar mayor, sin el consentimiento y expresa licencia de los tres patronos.

Las difuntas pagaban para ser enterradas en la iglesia del hospital cuatro ducados hasta 1663, pero desde entonces los patrones en una junta capitular determinaron que el costo de cada entierro aumentaría cien reales de vellón más, sumando ciento cuarenta y cuatro reales por cada entierro. ${ }^{97} \mathrm{El}$ aumento del costo del entierro en cripta del hospital, provocó mucho desconsuelo entre las moribundas que no querían ser enterradas en el campo santo. Esta situación fue comunicada por los curas en junta a los patrones, rectificándose y ordenándose volver a enterrar en la iglesia, pagando cuatro ducados, pero la mortaja y la capa se cobraban aparte. ${ }^{98}$ En los entierros de algunas madres mayores en la iglesia se solía

95ADPS. Legajo 4B. Ibidem, f. 47 v (1663). Esto fue determinado desde 1663 teniendo que pagar una limosna de cien reales para el hospital y pagando los derechos acostumbrados.

96 J. Bravo Lozano. "Fuentes para el estudio del trabajo femenino en la edad moderna: el caso de Madrid a fines del S. XVII", en Matilla, M. y Ortega, M. (eds.), El trabajo de las mujeres: siglos XVI- XX. Madrid: Universidad Autónoma de Madrid, 1996, pp.143-160.

97 ADPS. Legajo 4B. Libro de juntas o actas capitulares de patronos del hospital de las Cinco Llagas 1659-1687, f.48 v (14/03/1663): "Mandaron que en la iglesia de este hospital no se pueda enterrar ninguna difunta, sino fuere, habiendo mandado de limosna cien reales para el dicho hospital y pagando los derechos acostumbrados por razones que para ello hallaron"; ADPS. Legajo 4B. Libro de juntas o actas capitulares de patronos del hospital de las Cinco Llagas,1659-1687, f.59 v (21/08/1664): "Entierros en la iglesia no se hicieren, sino es dando cien reales más de los cuatro ducados que antes se daban por cada entierro"

98 ADPS. Ibidem, f.59 v (1664). Los curas indicaron que era mucho dinero dar ciento 
distribuir chocolate y regalos a las enfermas del hospital, que ellas pagaban como mandas testamentarias. ${ }^{99}$ Esta actitud se debía a que tuviesen presente a la difunta en sus rezos ya que la muerte no era tomada como un desconsuelo o tragedia, sino la liberación del alma del cuerpo para unirse con Dios. Pero para que eso se produjese, según sus creencias, se necesitaba cuantos rezos fuesen necesarios para aminorar el obstáculo que representaba el purgatorio. ${ }^{100}$

Desde 1664 se diferenciaron cada vez más los entierros de Iglesia de los de Campo Santo, aun cuando eran gratuitos se pagaba dos reales por misa rezada al cura semanero. Los entierros en iglesia eran más caros y se intentó aumentar su valor en 1663, sin éxito, regresando a su precio anterior, por las reiteradas suplicas de las enfermas, aunque pagando más por mortaja y capa del hospital, si es que no lo traían las susodichas. Desde 1664 en adelante permaneció a cuatro ducados cada entierro: dieciséis reales para el hospital y si llevaban mortaja seis reales más, percibiendo el hospital veinte y dos reales de limosna y si llevaban capa tres reales más, es decir, veinticinco reales. Lo restante se destinaba para pagar al cura, a los sacristanes y a los acompañantes que asistían a los entierros, el féretro, la sepultura, el paño y la cera empleada en la velación. Por ejemplo, en 1667, el hospital obtuvo un ingreso por entierro en iglesia de mil noventa y cinco reales, proveniente de cuarenta y cuatro entierros a veintidós reales, tres con capa a veinticinco reales y los tres restantes a menor precio por orden del administrador porque eran pobres y no tenían para satisfacer lo que faltó. Sin embargo, el entierro en la cripta de la iglesia proliferó a fines del siglo XVII, alcanzando su cenit en dicho siglo a comienzos del siglo XVIII.

cuarenta y cuatro reales por cada entierro "no se podían enterrar en dicha iglesia de que se seguia grande desconsuelo a las moribundas al ver que las habian de enterrar en el campos santo por no poder sus partes dar tanta limosna" "Los patronos decidieron anular el auto del 14/03/1663 y "mandaron que de aqui adelante se hagan los entierros en dicha iglesia en la conformidad que se hacian antes del dicho Auto, dando los dichos cuatro ducados aparte por cada entierro de todos derecho, excepto si no traen mortaja que por ella a de dar seis reales, y si fuere con capa a de dar tres reales más al hospital de las diez y seis reales que le tocan de cada entierro de suerte que si le pone la mortaja del hospital son veinte y dos reales y si con capas veinte cinco y se advierte a dichos curas que si ajustaren algún entierro por menos limosna no se le a de dar menos al hospital por dicho que va declarado, sino que entre ellos lo pierdan y que avisen al secretario de este hospital del entierro antes que se haga para que tome la razón". En los cuatro ducados estaba comprendido el pago que se tenía que realizar a los curas y acompañantes que asistían a los entierros. En 1663 no se enterró ninguna enferma en la iglesia, por lo que el hospital no había recibió ochocientos reales de vellón de los dieciséis que le tocaba en cada entierro, y tampoco los curas habían percibido entrada alguna. Se enterraban en iglesia, aproximadamente, cincuenta entierros anuales percibiendo el hospital la cantidad mencionada.

99 ADPS. Legajo 263. Memorias, testamentos, almonedas de bienes de difuntos, siglos XVIXVIII. En 1742, una enfermera del hospital pidió ser enterrada en una caja en la iglesia del hospital. Mandó que se distribuyesen seis libras de chocolate a las pobres del hospital al momento de su muerte para que la recordaran y rezaran por su alma.

100 P. García Hinojosa. Op. cit., p. 627. 
No es que se redujeran los entierros en Campo Santo del hospital, sino que aumentaron los de la iglesia. Así, en 1675, sesenta difuntos fueron enterrados en la iglesia, a un costo total de mil trescientos y veinte reales. Cada vez más, un mayor número de enfermas pedían ser enterrados con capas y mortajas del hospital, mientras que sólo sesenta y tres fueron enterradas en el campo santo del hospital con un ingreso de ciento y veintiséis reales.

En 1723, se dieron ciento y cuatro entierros en Campo Santo con un ingreso en arcas del hospital de doscientos y ocho reales (a dos reales cada uno por misa) y veintitrés entierros en la iglesia con un ingreso de quinientos reales de vellón. Las enterradas en cripta ya se enterraban con toda la parafernalia litúrgica, ninguna sólo con mortaja. ${ }^{101}$

Mientras que la venta de ropa de almoneda disminuyó, aumentó el número de entierros en la iglesia. Se buscaban medios para obtener dinero en el hospital. La diferencia en costo era evidente, si por el entierro en campo santo de ciento y tres difuntas a dos reales por la misa de cada una, ganaban los curas doscientos y seis reales. Entraban a las arcas del hospital mil trescientos y veinte reales por el entierro de sesenta difuntas con mortaja en la iglesia a veintidós reales por cada una y si usaban una capa durante la velación ascendía a mil quinientos y con velones aún más. A comienzos del siglo XVII casi todas las que se enterraban en la iglesia pagaban mortaja y capa. ${ }^{102}$

8. Almonedas: priores patronos, administrador, secretario notario, cura semanero madres enfermeras y doncellas de dote

La venta de la ropa de las fallecidas en hospital permitía cubrir, según fuese el caso, los gastos de entierro, misas y rezos. Las más pobres pagaban sus entierros en Campo Santo, sólo con la venta de sus ropas en almonedas. El hospital tenía por práctica y derecho adquirido por bulas apostólicas de disponer de la ropa y

101 M. Reder Gadow, "Vivencia de la muerte en el Antiguo Régimen”, en Baetica. Estudios de arte, geografía e historia. Málaga: Facultad de Filosofía y letras de la Universidad de Málaga, 9, 1986. p. 356. Presión social por mantener la jerarquía estamental en la muerte, perpetuando los códigos sociales de la vida

102 D. González Cruz y J. M. de Lara Rodenas, Op. cit., p. 290. Estos historiadores indican que para el periodo de 1700-1725 en este hospital de un total de 3589 entierros, el $90 \%$ eran efectuados en el campo santo del hospital y el $10 \%$ en la iglesia; ADPS. Legajo 183 . Libros anuales de capellanías, misas, memorias y otros gastos espirituales del hospital de las Cinco llagas (16951749). El incremento de los entierros en la iglesia del hospital se hizo evidente. Así, 31 entierros en 1658, 27 entierros en 1557, 16 entierros en 1664. En dicho año se pagaron 16 a 19 reales por entierro, porque traían sus propias mortajas, 52 entierros en 1665, alternado sin y con capa y mortaja, 45 entierros en 1666, alternado sin y con capa y mortaja, 50 entierros en 1667, alternado sin y con capa y mortaja, 57 entierros en 1670, alternado sin y con capa y mortaja, 60 entierros en 1671, alternado sin y con capa y mortaja, 22 entierros en 1692, todas con capa y mortaja del hospital, 39 entierros en 1694, todas con capa y mortaja del hospital. 
las alhajas que trajese en su persona la enferma que entraba a curarse y fallecía en él. El importe de las almonedas, generalmente, se convertía en misas rezadas por su alma. En el hospital de las Cinco Llagas se practicaban dos tipos de almonedas o subastas: la general y la particular. Además desde 1662 se determinó en junta patronal que las almonedas serían no sólo de los bienes ingresados al hospital, sino de los que las difuntas habían dejado afuera. ${ }^{103}$

En general, el producto de las almonedas generales se repartía entre los tres patronos para la realización de misas de difuntas y las de almonedas particulares entre todos los que participaban en una misa de difunta particular.

La almoneda general se hacía teniendo como base una minuta al pormenor que realizaba la madre mayor de lo que hubiere dejado la enferma al morir. A los dos meses se hacía la almoneda general de toda la ropa que constaba en las minutas, con la presencia del administrador y secretario quien anotaba la ganancia de las prendas vendidas. Se entregaba lo ganado al administrador, cargándosele por extraordinario en el libro de recibo y gasto, con la expresión correspondiente, para que los patronos mandasen decir las misas que cupiesen a la limosna ordinaria por iguales partes. ${ }^{104}$ Se trataba de ropas de diferentes difuntas que, generalmente, no habían tenido tiempo para testar o las más pobres. En estas almonedas concurría gente externa del hospital, como las macarenas que compraban ropa al por mayor.

Toda la ropa se regalaba a los pobres a comienzos del siglo XVI en el hospital de las Cinco Llagas, paralelamente se pusieron arquillas en la capilla del hospital en la parroquia de Santa Catalina para recaudar fondos hasta mediados del siglo XVI. Costumbre que se continuó en la iglesia del hospital en la Macarena. Dinero que se destinó a cubrir las necesidades espirituales de las difuntas. Sin embargo, estas dadivas fueron disminuyendo, por lo que se decidió vender la ropa de difuntas que ya se hacia en 1551. Las almonedas generales, como tales, empezaron a funcionar desde 1606. El objetivo era conseguir dinero para ayudar a las enfermas convalecientes y para las misas de difuntas, aunque con el tiempo, el primer objetivo se diluyó. El dinero recaudado de estas ventas se echaba en la arquilla y se abría en presencia del padre prior patrono visitador.

Desde 1606 a 1670, el dinero recaudado en las almonedas generales servía para que el administrador lo repartiese entre los pobres que salían convalecientes

103 ADPS. Legajo 4B. Libro de juntas o actas capitulares de patronos del hospital de las Cinco Llagas (1659-1687), f. 39 v (1662). "Los bienes que dejaron fuera no se desaparezcan, sino que se traigan y se cotejen con la memoria que de ellos dejó la difunta y se le entreguen a la madre mayor hasta el tiempo que se vendan y que el dinero que resultare de estas almonedas perteneciente a misas se ponga con cuenta y razón en el arquilla para esto diputada como el de las almonedas de la ropa que trajeron las enfermas cuando entraron y se guarden hasta la junta próxima siguiente para que se repartan entre los que pareciere a los Srs. patronos".

104 BC. Constitución de 1734. Const. 24. Acuerdo 1606, f. 56. Acuerdo 1582, f. 81. Acuerdo 1662, f. 39 v, f.76 r (1664). 
del hospital a modo de limosna. Se entregaba dos reales a cada una, según necesidad. Se invertía en ello sesenta, cuarenta o veinte reales. También parte del dinero recaudado se utilizaba para el transporte de las convalecientes a sus hogares $\mathrm{u}$ hospicios en las "sillas de caridad", haciendo uso de costaleros o carretas. El otro propósito de las almonedas generales era la realización de misas por las ánimas de las difuntas. La cantidad recaudada se repartía en tercias partes entre los frailes de los tres monasterios patronos del hospital que recibían un pago por realizar las misas, una vez, vendidas las ropas. ${ }^{105}$

Alguna ropa de las fallecidas en hospital se entregaba como limosna a los pobres, con anuencia del administrador. Se entregaba la ropa a personas que en verdad lo necesitaban. La ropa que se consideraba dudosa, contagiosa o de "escrúpulo"106, a juicio del médico y cirujano se mandaba enterrar o quemar para que no se usara de ella. ${ }^{107}$

Las almonedas fueron en progresiva disminución a lo largo del siglo XVII, al perder su importancia económica, se dejó de dar ayudas a los convalecientes. $\mathrm{Al}$ poco tiempo, en 1687, se determinó repartir el dinero proveniente de las almonedas generales en tres partes iguales, solamente, entre los patronos para que realizaran misas en sus conventos. ${ }^{108} \mathrm{En} 1638$ se realizaron diez almonedas, en 1640 , cinco almonedas y en 1648 , tres almonedas.

Sin embargo, el hospital cubrió este déficit de ingreso de dinero a las arcas del hospital, con el progresivo aumento de entierros en la iglesia del hospital que se iba incrementando en número a medida que se acercaba al siglo XVIII.

La almoneda particular se practicaba con la ropa de una determinada difunta. Además, estas almonedas se hacían con los bienes que la enferma dispuso en su testamento o declaración, a excepción de los que por libre voluntad regalaba. La ropa de las almonedas particulares se vendía entre las mujeres que trabajaban en el área femenina que eran muy afectas a comprar esta ropa subastada. Esto se entendía dentro de una sociedad preindustrial en el que la ropa era escasa. Se vendían: enaguas, sayas, delantales, camisas, cintas, pañuelos, mantillas, servilletas, toallas, rosarios, zarcillos, aretes, botones, zapatos, etc. ${ }^{109}$ La ropa vendida en almonedas particulares era ropa de mejor calidad que las ofrecidas en almonedas generales.

105 ADPS. Legajo 4B. Libro de juntas o actas capitulares de patronos del hospital de las Cinco Llagas (1659-1687), f.46 v (1663): "Que no se digan misas hasta estar echas las almas. Mandaron que no se digan la misa por las difuntas que mueren en este hospital hasta tanto que este vendida la ropa que dejaron y se sepa las que se han de ir".

106 Ropa de "escrúpulo" era las que usaban las mujeres al fallecer.

107 BC. Constitución 1734. Const. 25. Acuerdo 1578, f.73 r.

108 ADPS. Legajo 4B. Libro de juntas o actas capitulares de patronos del Hospital de las Cinco Llagas (1687-1715), f.3 r (1687).

109 BC. Constitución de 1734. Const. 26. Acuerdo 1671, f. 119. Acuerdo 1636, f. 125 v. Acuerdo de 1724, f. 46 r. 
Los curas que hacían los testamentos tenían que estar presentes en las almonedas particulares de las difuntas.

Se consignaba lo vendido y la ganancia en un libro de almonedas particulares. La subasta se hacía estando presente el secretario notario quien daba fe al acto y el administrador que como albacea testamentaria verificaba la cantidad de dinero recaudado que se convertiría en misas y, así, hacer cumplir la voluntad de la testadora. Además, el administrador se comprometía a verificar que se realizaran para que recibiesen la limosna los ministros eclesiásticos correspondientes, firmando al pie del asiento en el libro de almonedas. El hospital recibía el ocho por ciento de lo recaudado, cargándolos en el libro de recibo y gasto. El secretario del hospital tenía que ajustar las cuentas de las almonedas de las difuntas para poder cumplir con las misas por sus almas.

En 1658, las misas de almonedas de difuntas fueron realizadas por el cura segundo del hospital. ${ }^{10}$ Desde 1662, el administrador hizo que trajesen al hospital los bienes de que en los testamentos se disponían y se vendiesen en pública almoneda con asistencia del secretario para cumplir lo ordenado. Se solía esperar que los precios de las ropas subiesen para venderlas, pero el inconveniente era que se detenían las asistencias espirituales hacia las difuntas, por lo que se determinó que se vendieran desde 1738 a la brevedad posible. ${ }^{111}$ Algunas personas no lograron hacer testamento por muerte repentina u otro motivo. Sólo los bienes traídos al hospital por las personas fallecidas en calidad de abintestato podían ser subastados en almonedas particulares.

Misas cantadas y rezadas en la iglesia del hospital se celebraban con el dinero obtenido en las almonedas, así como capellanías y otras obras pías por disposiciones testamentarias. ${ }^{112}$ Los sacerdotes que decían las misas tenían la obligación de dar certificación jurada y firmada al pie de cada asiento de los libros que le correspondiese, lo cual ejecutaban ante el notario secretario para que el administrador les páguese la limosna tasada por los patronatos, y no estándolo, les pagaba lo acordado por los patrones del hospital en las juntas capitulares. Existía un libro cuadrante hasta 1649 , en el que llevaban la cuenta de las capellanías, misas canta-

110 ADPS. Legajo 4B. Libro de juntas o actas capitulares de patronos del hospital de las Cinco Llagas (1637-1658), f.335 v (1658).

111 ADPS. Legajo 4B. Libro de autos capitulares pertenecientes al gobierno de este hospital de la Sangre, comienza ańo de 1734 y acaba con junta de gobierno de 6 de diciembre de 1763. s/n de folio, f. 28 r (1738).

112 L.Gómez Nieto. Op. cit., pp. 81-101. Durante medio milenio, desde el siglo XII hasta el XVIII, la organización de las misas de difuntos se basó en la repetición y la acumulación. Los más pudientes fundaban capellanías de misas a perpetuidad que duraban hasta que sus rentas se acabaran. Las memorias eran un número reducido de misas anuales conmemorativas ligada a alguna fiesta señalada en el calendario litúrgico. Los aniversarios o misas celebradas el día de la muerte del contratante. Las misas acumulativas se hacían lo más cerca posible del deceso para reducir el tiempo de arrancia del alma o el tiempo del purgatorio. 
das, salves, entierros, procesiones de difuntas y memorias. En 1685 se ordenó que se volviera a usar. ${ }^{113}$ En el siglo XVIII, la distribución de las misas en este hospital disminuyó progresivamente. ${ }^{114}$

\section{La sala de San Pablo o de las agonizantes}

Desde comienzos del siglo XVII, el área de trabajo de las madres agonizantes y sus doncellas de dote era la sala de San Pablo, pero no en forma exclusiva. No sólo trabajaban en esta sala, sino también dormían en ella, compartiendo la habitación junto a las agonizantes, la madre incurable y sus doncellas. Esto se puede comprobar en los libros inventarios del hospital, en donde consta que en 1620, habían tres camas para la madre agonizante e incurable y su doncella, compartiendo sala con las enfermas de cámaras (treinta camas), enfermas incurables (veinte camas) y agonizantes. ${ }^{115}$

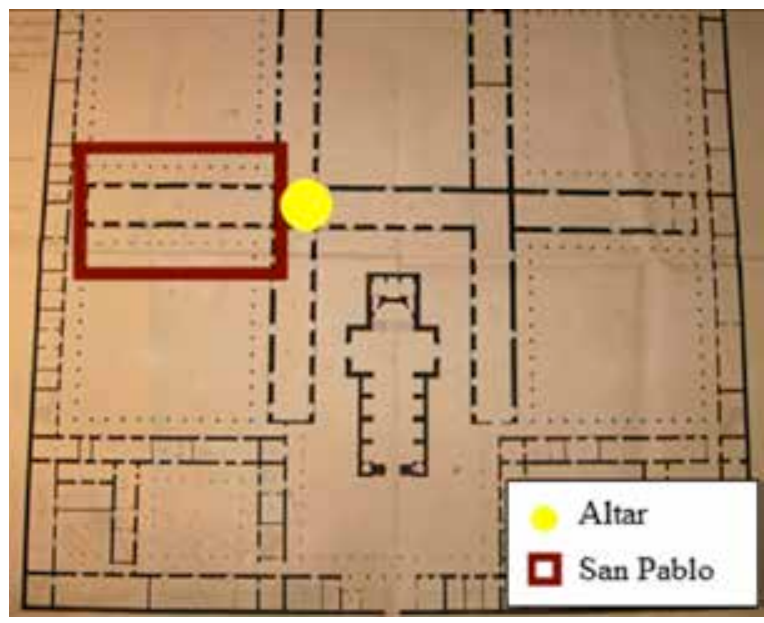

Figura 3. La ubicación de la sala de San Pablo o de las agonizantes. Fuente: A.D.S.P./ M.P.8

En 1622, en la sala de San Pablo había treinta camas. Generalmente se mantenían entre treinta y dos a treinta y tres camas para agonizantes, las que estaban numeradas. La iluminación de la habitación se llevaba a cabo con dos velones grandes de cuatro mecheros, veladores, candiles y aceiteras. El traslado de las fallecidas al amortajadero se hacía con tablas de madera con aros. También había en la habitación una cenefa grande de hierro para colocar los platos de las comidas, ca-

113 ADPS. Legajo 4B. Libro de juntas o actas capitulares de patronos del hospital de las Cinco Llagas (1659-1687), f.188 v (1685).

114 J.A.Rivas Alvarez, Op.cit., p. 253. En el año de 1701 se dieron un total de 1.293 misas. En 1750 un total de 321 y en 1799 un total de 44.

115 ADPS. Legajo 1A. Libro inventario de 1620. 
Tabla 2. La sala de San Pablo o de las agonizantes

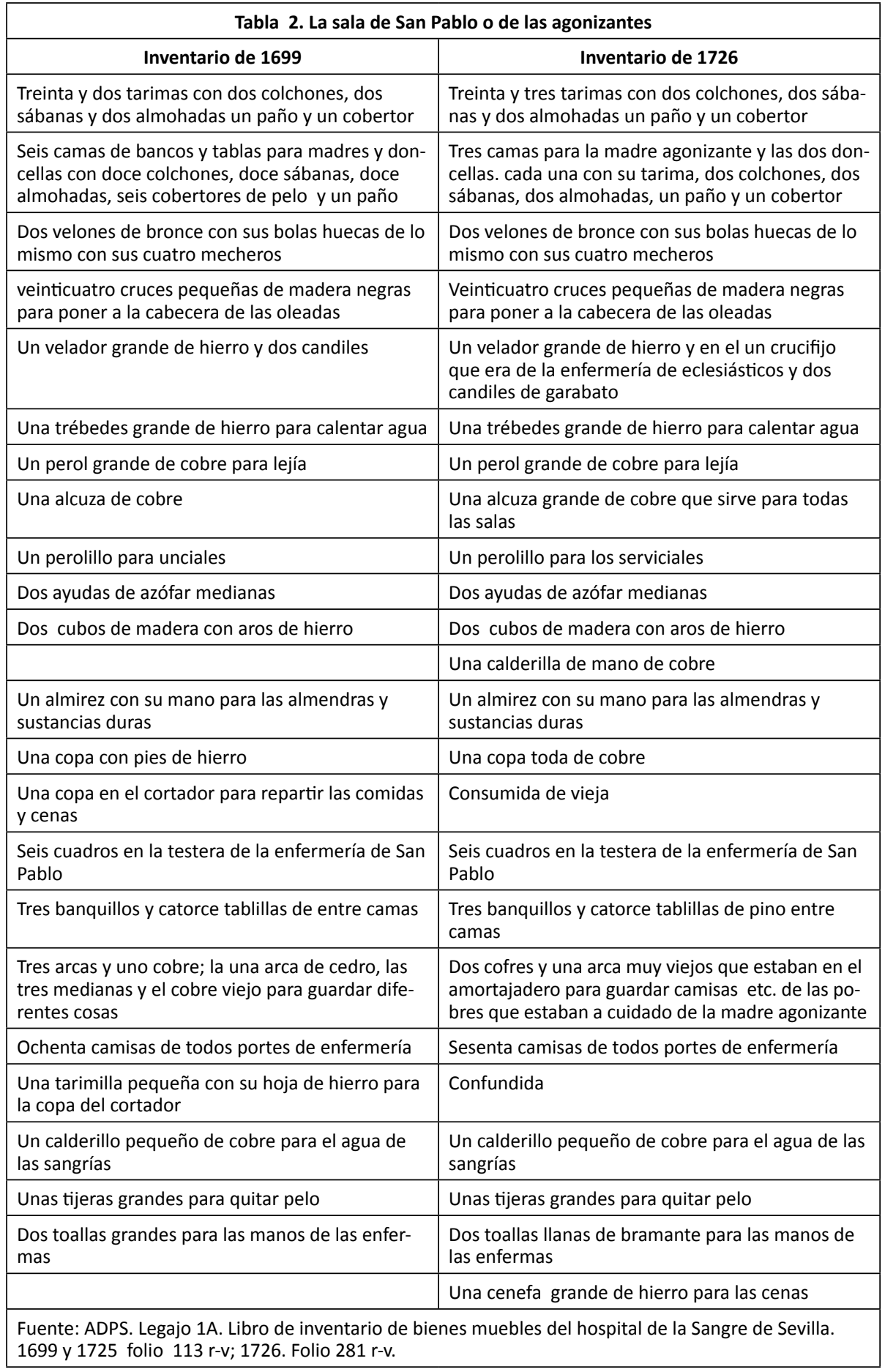


lentador de agua, tijeras para cortar los cabellos, toallas y calderilla para sangrías. Además, había banquillos y arcas para guardar camisas y otras cosas.

En el inventario de 1636, la Sala de San Pablo tenía tres camas, una para la madre agonizante y dos para las doncellas. Camas de con bancos y tablas, dos colchones, dos sábanas, dos almohadas, dos cobertores (uno de pelo y otro de paño). Dieciocho camas para las enfermas y dos tarimas altas usadas y siete tarimas bajas como camas de enfermas. Ya no estaban las enfermas de cámaras ni las incurables que se habían pasado a la sala de enfermería y al cuarto de incurables.

En la primera mitad del siglo XVIII, las agonizantes fueron separadas de las demás enfermas y concentradas en la Sala de San Pablo que se hallaba en la sala central entre las dos enfermerías de San Juan y San Pedro. Esta época coincidió con el barroquismo en el que la muerte ocupó el lugar central entre las demás enfermerías del hospital.

La sala de San Pablo era grande donde no sólo dormían las madres agonizantes sino otras madres, pues habia seis camas para estas madres y sus doncellas a finales de 1699. Sin embargo, esta sala fue ocupada exclusivamente por la madre agonizante, sus tres doncellas y sus treinta y tres enfermas, según los inventarios de 1725 y 1726.

Es interesante remarcar que a diferencia de las otras salas de enfermería, llenas de imágenes religiosas, la sala de San Pablo era parca en pinturas, ni tenían vírgenes de vestir, sólo cruces. El área de San Pablo o de las Agonizantes o de "cursientas" tenía frente de sí el altar mayor ubicada bajo la cúpula central, tanto en la planta baja y alta. Estos grandes y majestuosos altares se ubicaban en la intersección de las enfermerías de San Pedro (calenturas), San Juan (cirugía), San Pablo (agonizantes) y Convalecientes, tanto en la plata baja como alta.

\section{Conclusiones}

El cuidado de moribundas se consideraba una obra de misericordia realizada por verdaderos soldados de la fe y que cualquier persona piadosa lo podía realizar en calidad de asistente una vez que el cura lo ordenase. En el Antiguo régimen, la muerte era un acto público y se instaba a todo aquel que pudiese acompañase al moribundo porque la salvación era un trabajo colectivo para la cual el agonizante se debió haber preparado espiritual, social y materialmente durante toda su vida. Si bien, la preparación para la muerte fue atendida desde que se fundó el hospital en el siglo XVI, la madre del buen morir apareció formalmente en el hospital de las Cinco Llagas a comienzos del siglo XVII, a consecuencia de la obligación que tenía el hospital de proporcionar asistencia durante la agonía a cada enferma que el Concilio de Trento enfatizó y que el hospital eclesiástico estudiado acató y cumplió. Además, un cura ya no podía cumplir con todas las obligaciones espirituales de las enfermas que tenía el hospital al haber aumentado su número y porque el área femenina del hospital tenía entrada restringida a los varones, in- 
cluso a los curas. Sólo uno de ellos podía hacerlo durante una semana. Ante esta necesidad espiritual, los patronos recurrieron a beatas para ayudar a bien morir a comienzos del siglo XVII.

Después que el cura realizara los sacramentos de confesión, penitencia, comunión y extremaunción, la madre del buen morir asistía a la moribunda en la última lucha por su salvación, leyéndole oraciones de diversos santos y clausulas cortas para alejarla de las tentaciones y peligros contra el alma. La necesidad de asistencia espiritual durante la muerte entre las enfermas aumentó a medida que avanzaban los siglos de la Edad Moderna. Lo que resulta contradictorio, pues mientras que la élite empezaba a cuestionar los ritos, el pueblo adoptó cada vez más los rituales. De esta manera, el número de madres agonizantes aumentó a dos desde mediados del siglo XVIII. Estas madres se turnaban de día y de noche para que la agonizante no muriese sola sin asistencia espiritual.

El ritual y la parafernalia mortuoria aumentaron considerablemente entre las enfermas de este hospital a mediados del siglo XVIII. Y es cuando la muerte se convirtió entre los pobres de este hospital en la actriz principal privilegiándola, prefiriendo una tumba en cripta que en campo santo y disminuyendo la compra de ropa en almonedas en el hospital, cuyo ingreso se equilibra con el pago de misas y otros servicios funerarios que todos hasta los más pobres querían acceder.

$\mathrm{Al}$ menos en este hospital sevillano, la muerte se fue haciendo más importante en las personas que fallecían en este hospital en el siglo XVIII que en los siglos anteriores. De ahí que cada vez fuese más necesaria la presencia de madres agonizantes. Los enfermos no clamaban por médicos sino por curas y personas que les asistiesen en la agonía y su última lucha entre el bien y el mal. Así, el ritual funerario se acentuó entre los pobres quienes pagaban no sólo bulas y misas sino también entierro en la cripta de la iglesia, hábitos como mortaja, capas, velones, acompañantes, convites, regalos y por lo tanto exigían al hospital mayor cantidad de madres del buen morir entre 1726 a 1809.

Es decir, en este hospital sevillano a comienzos del siglo XIX no se produjo una laicización abrupta y si se dio no fue por motivos religiosos sino por coyunturas económicas (desamortizaciones), sociales y políticas tan impactantes como la Guerra de la independencia del dominio francés que quebraron el antiguo sistema y eso se visualiza con la desaparición de las madres agonizantes del hospital estudiado. 